\title{
ARTICLES \\ EMPOWERING THE POOR: TURNING DE FACTO RIGHTS INTO COLLATERALIZED CREDIT
}

\author{
Steven L. Schwarcz*
}

The shrinking middle class and the widening gap between rich and poor threaten social and financial stability. Though sometimes identified as a problem of developing nations, the inability of the poor to obtain credit by using their de facto rights in property as collateral impedes upward mobility in nearly all countries, including the United States. Efforts to solve this problem have focused on trying to transform de facto rights into de jure title under property law. Those efforts have been unsuccessful because, among other reasons, property law is tightly bound to tradition and protecting vested ownership. This Article proposes an innovative but balanced approach to solving the credit problem. Credit is a commercial activity, and modern commercial law increasingly recognizes important policy goals and realities as a justification for overriding outmoded property-law limitations. Commercial law should recognize the importance of reducing the wealth gap as a justification for allowing the poor to use their de facto rights in property as collateral. That not only would help to empower the poor with credit but also would facilitate sustainable finance that attracts arm's-length funding to supplement charitable and public resources.

(C) 2019 Steven L. Schwarcz. Individuals and nonprofit institutions may reproduce and distribute copies of this Article in any format at or below cost, for educational purposes, so long as each copy identifies the author, provides a citation to the Notre Dame Law Review, and includes this provision in the copyright notice.

* Stanley A. Star Professor of Law \& Business, Duke University School of Law; Senior Fellow, the Centre for International Governance Innovation (CIGI); and Distinguished Visiting Professor, University College London (UCL) Faculty of Laws (Spring 2018). For helpful comments, the author thanks John Armour, John Borrows, Giuliano Castellano, Iris H. Chiu, Erica Field, Alfredo Gutierrez Girault, Sean J. Griffith, Heather Hughes, Odette Lineau, Ben McFarlane, Christoph Paulus, Maziar Peihani, Irit Ronen-Mevorach, Matteo Salinas, Daniel Schwarcz, Michael Simkovic, Xiao Yu Wang, and participants in the Distinguished Visiting Professorship Lecture at University College London Faculty of Laws, the University of Durham Honorary Professorship Inaugural Lecture, the Doctorate College Lecture at Humboldt University of Berlin Faculty of Law, the CLC Lecture at Harris Manchester College, University of Oxford, and faculty workshops at Duke Law School and University of Glasgow School of Law. He also thanks Ryan Arredondo, Miata Eggerly, Jiazhen Yan, and especially Kris Liu for valuable research assistance. 


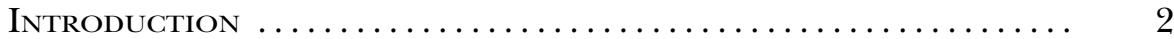

I. Explaining How and Why Commercial Law Overrides

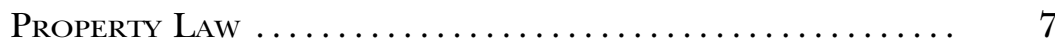

II. Explaining Why Commercial Law Should Override Property Law to Empower the Poor...............

A. How Could Holders of De Facto Rights Transfer More Rights than They Hold? ............................

B. Would Recognition of That Transfer Be Unfair to Holders of De Jure Rights?............................ 14

C. How Could the De Facto Rights Be Clearly Identified?..... $\quad 19$

D. Would Lenders Be Prepared to Extend Credit?........... 22

E. Would the Poor Be Willing to Borrow? ............. 28

III. Explaining Why Overriding Property Law to Empower the Poor Would Be Economically Efficient ......... 29

A. Estimating Anticipated Benefits................... 29

B. Estimating Anticipated Costs ................. 30

C. Balancing Costs and Benefits .................. 33

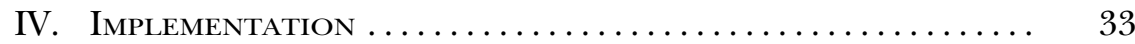

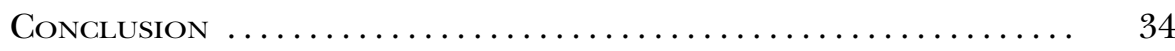

Annex: Model Law to Recognize De Facto Property Rights... 35

\section{INTRODUCTION}

The shrinking middle class and the widening gap between the rich and the poor threaten social and financial stability. ${ }^{1}$ The World Economic Forum, ${ }^{2}$ the United Nations, ${ }^{3}$ and recent surveys ${ }^{4}$ have identified this wealth inequality as one of the greatest risks to the global community. The noted economist Hernando de Soto explains how the inability of the poor to obtain credit increases this inequality. ${ }^{5}$

1 See, e.g., R.A., How Inequality Affects Growth, Economist (June 15, 2015), https:// www.economist.com/blogs/economist-explains/2015/06/economist-explains-11 (discussing "recent work suggest[ing] that inequality [in wealth] could lead to economic or financial instability").

2 World Economic Forum, Global Risks 2014, Ninth Edition 13-14 (2014).

3 G.A. Res. 70/1, at 14 (Sept. 25, 2015) (positing that the most important goal of the international community should be to "[e]nd poverty in all its forms everywhere").

4 See, e.g., Michelle Ma, How to Fix the World, Wall St. J. (Jan. 21, 2019), https:// www.wsj.com/articles/how-to-fix-the-world-11548070200 (reporting the results of a reader survey identifying the "vanishing middle class" in the global economy as the top issue that "should be government and business leaders' first priority").

5 See Hernando de Soto, The Mystery of Capital 18-22 (2000). Although de Soto's argument and its implications for transforming informal housing to formal title have become a cornerstone of many development programs, some empirical analyses have questioned the impact of policies based on his argument. See, e.g., Timothy Mitchell, The Work of Economics: How a Discipline Makes Its World, 46 Eur. J. Soc. 297, 309 (2005) (discussing the criticisms). Nonetheless, the connection between property rights and access to credit 
The poor hold their resources in defective form, de Soto argues. ${ }^{6}$ They live in houses built on land that, de facto, is theirs but not legally recorded as their property. ${ }^{7}$ As a result, they often cannot use their homes as collateral to borrow and create wealth-mortgage lending being the primary source of capital used to start small businesses. ${ }^{8}$ Others more recently have confirmed that without the ability to borrow by using their homes as collateral, the poor are "unable to leverage their resources to create wealth, and their assets become 'dead capital' which cannot be used to generate income or growth."

This is both a U.S. and a worldwide problem. Members of rural African American communities, for example, commonly lack registered title to their land. ${ }^{10}$ They therefore "cannot use the land as collateral for home mortgages or farming loans." 11 Recent efforts in Puerto Rico to obtain U.S. government assistance in the aftermath of Hurricane Maria revealed that over half of that island's residents "lack title" to their houses. ${ }^{12}$

remains a central tenet of the current efforts to alleviate poverty. See, e.g., Peer Stein, Tony Goland \& Robert Schiff, Two Trillion and Counting 1, 9 (2010).

6 DE Soto, supra note 5, at 19.

$7 \quad I d$

8 Id.

9 Chris Arsenault, Property Rights for World's Poor Could Unlock Trillions in 'Dead Capital': Economist, Reuters (Aug. 1, 2016), https://www.reuters.com/article/us-global-landrightsdesoto/property-rights-for-worlds-poor-could-unlock-trillions-in-dead-capital-economist-id USKCN10C1C1; see also, e.g., STEIN ET AL., supra note 5, at 6. The poor also hold other assets that cannot currently be used as collateral due to legal constraints. See, e.g., Heywood Fleisig, Secured Transactions: The Power of Collateral, Fin. \& Dev., June 1996, at 44. For example, legal constraints prevent movable property, such as cattle, from being used as collateral by farmers in countries like Uruguay, whereas cattle are one of the best forms of collateral in the United States. Id. at 45. Merchants in developing countries who would be willing to extend credit to poor farmers also may be legally constrained from taking inventory or accounts receivable as collateral. Id. at 45-46.

10 Janice F. Dyer, Statutory Impacts of Heir Property: An Examination of Appellate and Macon County Court Cases 2 (unpublished paper presented at the 66th Annual Professional Agricultural Workers Conference, Tuskegee University, Dec. 7-9, 2008), http:// citeseerx.ist.psu.edu/viewdoc/download?doi=10.1.1.569.1533\&rep=rep1\&typepdf; see also Joan Flocks, Sean P. Lynch II \& Andréa M. Szabo, The Disproportionate Impact of Heirs' Property in Florida's Low-Income Communities of Color, 92 FLA. B.J. 57, 57 (2018) (observing that as a result of intestate succession creating multiple fractional interests in real estate, heirs have clouded title to their homes; and also finding that "this problem is especially prevalent in the southeastern United States" and "disproportionately affect[s] African-American households, particularly in low-income communities”); Lizzie Presser, The Dispossessed, New YORKER, July 22, 2019, at 28, 28 (quoting the U.S. Department of Agriculture's characterization of heirs' property as "the leading cause of Black involuntary land loss," and estimating that heirs' property "make[s] up more than a third of Southern black-owned land-3.5 million acres, worth more than twenty-eight billion dollars").

11 Dyer, supra note 10, at 3; see also Flocks et al., supra note 10, at 57 (finding that African Americans in low-income communities, especially in southeastern United States, cannot use their land as collateral).

12 Adrian Florido, Unable to Prove They Own Their Homes, Puerto Ricans Denied FEMA Help, NPR (Mar. 20, 2018), https://www.npr.org/2018/03/20/595240841/unable-toprove-they-own-their-homes-puerto-ricans-denied-fema-help (reporting that "the island's 
More broadly, the World Bank estimates that, largely due to poverty, seventy percent of the world's population lacks registered title to their land. ${ }^{13}$ As the U.S. experience shows, this is a problem even for developed countries. ${ }^{14}$ In Canada, for example, the indigenous First Nations people hold interests in their land that "may not be immediately registerable under" land title statutes, making those interests unmarketable and unable to be used as collateral. ${ }^{15}$

The inability of the poor to use their homes as collateral to borrow and create wealth poses an important challenge: Should the law recognize de facto rights-that is, rights that are recognized or respected in practice but not formally under (official) law ${ }^{16}$ - to enable the poor and other economically disadvantaged people (collectively, the "economically disadvantaged") to use their homes and other commonly held assets as collateral, to obtain credit? Ending poverty requires bridging this "credit gap." 17 Credit is essential to economic growth and upward mobility:

Suppose you live in a medieval town that suffers from annual outbreaks of dysentery. You resolve to find a cure. You need funding to set up a workshop, buy medicinal herbs and exotic chemicals, pay assistants and travel to consult with famous doctors. You also need money to feed yourself and your family while you are busy with your research. . . .

... But how can you get the money when ... all your time is taken up with research? Reluctantly, you go back to tilling your field, dysentery keeps tormenting the townsfolk, [and] nobody tries to develop new remedies .... That's how the economy languished and science stood still.

The cycle was eventually broken in the modern age thanks to people's growing trust in the future, and the resulting miracle of credit. ${ }^{18}$

The efforts to date to meet this challenge have failed because they focus on trying to transform de facto rights into de jure title under property law. ${ }^{19}$

government estimates that more than half of houses here are 'informal'-meaning they . . lack title").

13 Why Secure Land Rights Matter, World BANK (Mar. 24, 2017), http://www.worldbank. org/en/news/feature/2017/03/24/why-secure-land-rights-matter. The World Bank observed that, in many parts of the world, people simply do not know what their property rights are and, even if they try to find out, they cannot receive accurate information from government agencies. Id.

14 See id. (stating that in the Republic of Macedonia, for example, only one-third of the apartments had registered title).

15 John Borrows, Aboriginal Title and Private Property, 71 Sup. CT. L. Rev. 91, 115-16 (2015).

16 See Legal English: "De Facto/De Jure,” Wash. U. ST. Louis (Dec. 28, 2012), https:// onlinelaw.wustl.edu/blog/legal-english-de-factode-jure/ (observing that "de facto refers to situations that are true for practical reasons, whereas de jure refers to formal, official status of the matter").

17 STEIN ET AL., supra note 5, at 2, 9.

18 Yuval Noah Harari, Homo Deus 203-04 (HarperCollins 2017) (2015).

19 Cf. Manny Jules, Foreword to Tom Flanagan, Christopher Alcantara \& André Le Dressay, Beyond the Indian Act, at xi (2010) ("To fully realize the full value of our land 
Property law is difficult to transform, however, being tightly bound to tradition and protecting vested ownership. ${ }^{20}$ Weak or conflicting property-law regimes can also impede transformation, as evidenced by certain failed property-titling programs. ${ }^{21}$ Leading scholars also explain the failure by observing that, "[i] ronically, property titling programs might actually reduce banks' ability to foreclose [thus undermining their willingness to extend credit] because [such programs] unavoidably send the message that governments will side with poor borrowers in enforcing credit contracts." 22

This Article meets the challenge by taking an innovative but balanced approach: focusing on using commercial law, rather than property law, to enable the economically disadvantaged to use their de facto rights as collateral to obtain credit. ${ }^{23}$ That use of commercial law, this Article shows, would be consistent with modern principles of commercial law, which increasingly recognize important policy goals and commercial realities as a basis to override outmoded limitations imposed by property law. It also would be economically efficient, fair to vested owners, and easy to implement.

Enabling the economically disadvantaged to use their rights as collateral to obtain credit would also create an important new source of "sustainable finance," a term that encompasses financial innovations that benefit both the private sector and society at large. ${ }^{24}$ Virtually all existing forms of sustainable

we need a secure property-rights system.”); Michael Trebilcock \& Paul-Erik Veel, Property Rights and Development: The Contingent Case for Formalization, 30 U. PA. J. INT'L L. 397, 406 (2008) (arguing that collateral is not effective unless the borrower has "secure ownership of the property" that constitutes the collateral); infra notes 155-66 and accompanying text (discussing the limitations of property-titling programs intended to encourage banks to extend credit to economically disadvantaged borrowers).

20 See, e.g., Alfred L. Brophy, Hernando de Soto and the Histories of Property Law, in HeRnando de Soto and Property in a Market Economy 51, 52 (D. Benjamin Barros ed., 2010) (explaining that despite the United States' occasional recognition of squatters' informal property rights, "property law in the United States was then-and continues today-to be primarily about the protection of vested rights"); cf. Glen SEAn Coulthard, Red Skin, White Masks 74-75 (2014) (observing that a proposal by indigenous tribes in Canada, which would have transformed the Northwest Territories into an indigenous-based property system, was "interpreted as violating what many northerners had come to consider an 'inalienable right' to own property").

21 See infra note 164 and accompanying text.

22 Erica Field \& Maximo Torero, Do Property Titles Increase Credit Access Among the Urban Poor? Evidence from a Nationwide Titling Program 24 (Mar. 2006) (unpublished paper), https://scholar.harvard.edu/files/field/files/fieldtorerocs.pdf.

23 Absent that recognition, the economically disadvantaged will remain unable to borrow. See, e.g., Staff of H.R. Select Comm. on Hunger, 100th Cong., Access and Availability of Credit to the Poor in Developing Countries and the U.S. 1 (Comm. Print 1987) (finding that collateral requirements imposed by financial institutions prevent the poor from gaining access to credit); Trebilcock \& Veel, supra note 19, at 406-07.

24 Thomas Clarke \& Martijn Boersma, Sustainable Finance? A Critical Analysis of the Regulation, Policies, Strategies, Implementation and Reporting on Sustainability in International Finance 4-5 (United Nations Env't Programme, Working Paper 16/03, 2016) (discussing sustainable finance from a broader environmental, social, and governance perspective). 
finance depend on charitable or public sources of funding, ${ }^{25}$ which are limited and unreliable, ${ }^{26}$ or on mandatory regulation of finance to impose social responsibility. ${ }^{27}$ In contrast, this Article's new vision of sustainable finance is designed to attract arm's-length commercial funding sources. ${ }^{28}$

This new vision is also consistent with government efforts to mobilize private-sector finance for sustainable growth. The European Union, for example, recognizes that because "the scale of the [sustainable growth] investment challenge is beyond the capacity of the public sector alone," the private "financial sector has a key role to play in reaching those goals." ${ }^{9}$ To try to facilitate that role, the EU recently adopted an action plan on sustainable finance that included the objective of "reorient[ing] capital flows towards sustainable investment in order to achieve sustainable and inclusive growth." ${ }^{30}$ This Article would squarely meet that objective. ${ }^{31}$

25 Steven L. Schwarcz, Disintermediating Avarice: A Legal Framework for Commercially Sustainable Microfinance, 2011 U. ILL. L. REv. 1165, 1167 ("Historically, the majority of microfinance activities had been confined to the on-lending of funds provided by charitable donors ...."). This Article's vision of recognizing de facto rights to collateralize credit is also fundamentally different from the credit provided by microfinance, which does not rely on collateral: "Micro-credit does not rely on the borrower's title to his or (more frequently) her assets as collateral or as a source of repayment to the lender. It relies on the borrower's appreciation of the importance of the loan and corresponding willingness to repay it." Boris Kozolchyk, Secured Lending and Its Poverty Reduction Effect, 42 Tex. InT'L L.J. 727, 731 (2007).

26 See Schwarcz, supra note 25, at 1167-68 (“[T] he need for microfinance lending vastly exceeds the amount of funds that can be raised from charitable donors. It is estimated, for example, that of the 1.5 billion people potentially eligible for microfinance loans, only 100 million people-less than 7\%-receive them." (footnote omitted)); cf. infra note 29 and accompanying text (finding that the sustainable growth investment challenge is beyond the capacity of the public sector).

27 Clarke \& Boersma, supra note 24, at 4.

28 See infra Section II.D (explaining why lenders would be prepared to extend credit).

29 Sustainable Finance, Eur. Commission, https://ec.europa.eu/info/business-economy-euro/banking-and-finance/sustainable-finance_en (last visited Sept. 7, 2019). To this end, the European Commission established a High-Level Expert Group on Sustainable Finance in December 2016, with a mandate to "steer the flow of public and private capital towards sustainable investments." Id. That Group concluded that it will be important to "look [ ] into regulatory changes to mobilise the significant funding capacity of private capital." Valdis Dombrovskis (Vice President for the Euro and Social Dialogue) \& Jyrki Katainen (Vice President for Jobs, Growth, Investment and Competitiveness), Foreword to EU High-Level Expert Grp. on Sustainable Fin., Financing a Sustainable European Economy, at 2 (2018).

30 Communication from the Commission to the European Parliament et al., Action Plan: Financing Sustainable Growth, § 1, COM (2018) 97 final (Mar. 8, 2018).

31 The EU's action plan contemplates the possibility of making regulatory changes, focusing on recalibrating bank capital requirements to take into account risks arising from unsustainability. $I d . \$ 3.3$. Capital requirements, however, are highly intrusive and socially costly. They can cut into global economic output and job growth by reducing bank lending and creating a credit shortfall. See, e.g., Jean Dermine, Bank Regulations After the Global Financial Crisis: Good Intentions and Unintended Evil, 19 Eur. Fin. MGmt. 658, 661-62 (2013) ("Or, if capital is excessive, it might lead to inefficiently higher interest rates on bank 
This Article proceeds as follows. To underpin the normative analysis, Part I explains how and why commercial law currently overrides property law. This approach follows the strong scholarly precedent for grafting a normative legal inquiry onto positive-law reality. ${ }^{32}$ Part II then explains how and why commercial law should override property law to enable the economically disadvantaged to use their de facto rights as collateral to obtain credit. Thereafter, Part III explains why overriding property law in that way would be economically efficient, generating benefits that exceed its costs. Part IV of this Article examines how to implement this legal framework, comparing statutory and judicial approaches. Finally, the Annex to this Article proposes the text of a model law that could form the basis of a statutory approach (the "Model Law").

\section{Explaining How and Why Commercial Law Overrides Property Law}

Commercial law increasingly recognizes important policy goals and commercial realities as a basis to override certain property-law limitations. ${ }^{33}$ Although there are many examples, ${ }^{34}$ the dominant precedent is the Uni-

loans ... . [I]n a dynamic perspective, private costs may induce social costs as banks reduce their supply of loans or securitise assets.”); Jacob A. Bikker \& Haixia Hu, Cyclical Patterns in Profits, Provisioning and Lending of Banks and Procyclicality of the New Basel Capital Requirements, 55 Banca Nazionale del Lavoro Quart. Rev. 143, 144 (2002) (arguing that capital requirements might reduce bank lending, thereby causing a credit shortfall that would harm the public); Reint Gropp et al., Bank Response to Higher Capital Requirements: Evidence from a Quasi-Natural Experiment 1 (Halle Inst. for Econ. Research, IWH Discussion Paper No. 33, 2016), https://www.econstor.eu/bitstream/10419/148361/1/874406 994.pdf (finding that higher bank capital requirements cause banks to increase their capital ratios "not by raising their levels of equity, but by reducing their credit supply," resulting in lower firm, investment, and sales growth). This Article's legal solution is more highly targeted-focusing on changing commercial law to enable the poor to use their de facto rights as collateral in order to start small businesses.

32 See, e.g., Lucian Arye Bebchuk, A New Approach to Corporate Reorganizations, 101 HaRv. L. REv. 775, 776-77 (1988) (grafting a normative analysis of bankruptcy law (what should be "the best method for dividing the [corporate] reorganization pie") onto a positive assumption about that law (taking as given the widespread use of the corporate reorganization alternative to liquidation)); $c f$. Noel Annan, Introduction to Isaiah Berlin, Personal Impressions, at xv, xxi (Henry Hardy ed., Princeton Univ. Press 2001) (1980) (arguing that norms are and should be factually based and tethered to reality).

33 By observing that commercial law sometimes "overrides" property law in those circumstances, I am not making a general normative claim about relationships between commercial law and property law or among those bodies of law and contract law. Rather, I am simply observing that legislatures sometimes enact provisions of commercial law that, by their terms, explicitly override property law. See infra notes 34 \& 40-52 and accompanying text (discussing statutory provisions of commercial law that override property law in the United States, Germany, Japan, and Chile).

34 Many nations' commercial law recognizes policy goals and commercial realities as a basis to override outmoded limitations imposed by property law. In Germany, for example, a "bona fide acquirer may obtain the ownership of a chattel under certain circumstances [even when] the transferor is neither the owner of the chattel nor authorized by the owner to dispose thereof." Karsten Thorn, Germany, in Transfer of Ownership IN 
form Commercial Code (UCC), perhaps the world's most respected codification of commercial law. ${ }^{35}$ The UCC is a model law that is promulgated and continuously updated by the American Law Institute and the Uniform Law Commission. The American Law Institute, with worldwide membership, is "the leading independent organization in the United States producing scholarly work to clarify, modernize, and otherwise improve the law." 36 The Uniform Law Commission provides "non-partisan, well-conceived and welldrafted legislation that brings clarity and stability to critical areas of state statutory law." 37 This Article builds on the foundation provided by the UCC, ${ }^{38}$ among other sources. ${ }^{39}$

The UCC overrides property law in order to recognize important commercial realities that clash with the "arbitrary shifting" of rights based on

International Trade 203, 211 (Alexander von Ziegler et al. eds., 2d ed. 2011); see also Bürgerliches Gesetzbuch [BGB] [Civil Code], §932, para. 1, translation at http:// www.gesetze-im-internet.de/englisch_bgb/index.html (Ger.) (allowing good-faith acquirers of property to obtain ownership of chattel); BGB, § 892, translation at http:// www.gesetze-im-internet.de/englisch_bgb/index.html (presuming accuracy of the contents of land registry); Handelsgesetzbuch [HGB] [Commercial Code], \$ 366, para. 1 (applying these provisions of the civil code to commercial transactions in some circumstances). The justification is that it is often unreasonable or even impossible for the acquirer to verify the property relations before transaction. This "result is accepted in order to sustain trade and commerce" even though it "effectively leads to an expropriation of [property of] the owner." Thorn, supra, at 211. Japan's commercial law is similar. Tomotaka Fujita, Japan, in Transfer of OWnership in International Trade, supra, at 261, 264 (recognizing that one who acquires "the possession of movables peacefully and openly by a transactional act acquires rights" in such movables if he is in "good faith and without fault") (quoting MinPo [MinPo] [Civ. C.] art. 192 (Japan)). Chile goes even further, recognizing that the "social function of . . . ownership" makes ownership subordinate to requirements of "the Nation, the national security, the public utility and health and the preservation of the environment.” Luis Felipe Lira Guzmán \& Hernán A. Pitto, Chile, in Transfer of Ownership in International Trade, supra, at 83, 90 (citing Constitución Política de la República de Chile [C.P.] art. 19).

35 Cf. Roy Goode, The Codification of Commercial Law, 14 Monash U. L. Rev. 135, 137 (1988) (describing the Uniform Commercial Code as the "most ambitious codification of commercial law ever attempted in any jurisdiction").

36 About ALI, Am. L. INst., https://www.ali.org/about-ali (last visited Sept. 7, 2019).

37 Overview, Uniform L. Commission, https://www.uniformlaws.org/aboutulc/overview (last visited Sept. 7, 2019).

38 The UCC applies to security interests in personal property but not real estate. U.C.C. § 9-109(d)(11) (Am. Law Inst. \& Unif. Law Comm'n 2018). The real estate exclusion, however, is due to self-interested lobbying by the real estate bar. See, e.g., Robert K. Rasmussen, The Uneasy Case Against the Uniform Commercial Code, 62 LA. L. Rev. 1097, 1112-13 (2002) (observing that local real-estate bars preferred non-UCC lack of uniformity for rent-seeking purposes, requiring the hiring of local lawyers for real property transactions and creating an entry barrier for out-of-state lawyers seeking bar admission). Because the UCC's innovative principles-such as the disentanglement of commercial and property law-are compelling and should logically apply regardless of whether the property at issue is personal or real estate, this Article's analysis does not distinguish that nature of the collateral except as specifically indicated. Cf. infra Annex, Model Law art. 1(1) (stating that such Law applies to security interests in both personal property and real property). 
property. ${ }^{40}$ For example, UCC $§ 9-202$ provides, with very limited exceptions, that "the provisions of this article [9] with regard to rights and obligations apply whether title to collateral is in the secured party or the debtor." 41 This enables commercial law to recognize the reality that " $[t]$ he retention or reservation of title by a seller of goods notwithstanding shipment or delivery to the buyer . . . is limited in effect to a reservation of a 'security interest." 42 That recognition "provides a clearer and more coherent system for dealing with . . . conflicts" over competing rights. ${ }^{43}$

Similarly, UCC § 2-401 provides (again, with very limited exceptions) that each "provision of this Article [2] with regard to the rights, obligations and remedies of the seller, the buyer, purchasers or other third parties applies irrespective of title to the goods." ${ }^{4}$ This enables commercial law to recognize the reality that the risk of losing goods in shipment should be allocated to the party who "control[s] the goods and can be expected to insure his interest in them," 45 whether or not that party owns the goods at the time of their loss. ${ }^{46}$ Commercial law's recognition of that reality is widely touted as providing "enormous" gains "in clarity, translatability and practicability." 47 It has also become the basis for allocating risk of loss under the United Nations Convention on Contracts for the International Sale of Goods (CISG). ${ }^{48}$

39 Cf. supra note 34 (providing examples of non-UCC commercial law that likewise recognizes policy goals and commercial realities as a basis to override property-law limitations).

40 U.C.C. $\$ 2-509 \mathrm{cmt} .1$ (observing that the "underlying theory" is to avoid "an arbitrary shifting of the risk with the "property' in the goods"). The UCC itself does not yet clearly embrace the recognition of de facto rights as a basis to grant a security interest. See $i d$. § 9-203(b) (2) \& cmt. 6 (requiring the debtor to have "rights in the collateral" as a condition of granting a security interest therein, but not discussing whether de facto rights might suffice). But cf. Michael Bridge \& Jo Braithwaite, Private Law and Financial Crises, 13 J. CoRp. L. STud. 361, 397 (2013) (discussing how conflating contract and property in derivatives transactions in insolvency can jeopardize financial stability).

41 U.C.C. $\$ 9-202$.

42 Id. § 1-201(b) (35) (defining a security interest).

43 Sean Thomas, The Role of Authorization in Title Conflicts Involving Retention of Title Clauses: Some American Lessons, 43 Common L. World Rev. 29, 30 (2014).

44 U.C.C. \$ 2-401.

$45 \quad I d . \$ 2-509 \mathrm{cmt} .3$.

46 See id. § 2-509.

47 John Honnold, The New Uniform Law for International Sales and the UCC: A Comparison, 18 InT'L Law. 21, 27 (1984). Recognition of reality strongly influences the UCC. See Henry E. Smith, On the Economy of Concepts in Property, 160 U. PA. L. Rev. 2097, 2124 (2012) ("In drafting the Uniform Commercial Code, Llewellyn set out to diminish the importance of title, a decision fully justified according to the Realist-inspired conventional wisdom.").

48 See Honnold, supra note 47, at 27 (discussing the CISG's rules in articles 66-70 for allocating risk of loss and observing that "rules on risk of loss are closely patterned on the modern rules of the UCC. The approach is the same: the elusive concept of property . . is not employed. Instead, the Convention's rules are drafted in terms of concrete commercial events-handing over goods to the carrier and the buyer's 'taking over' physical possession from the seller." (footnote omitted)). 
The UCC also overrides property law to recognize important policy goals. For example, to facilitate the transferability of goods, it gives goodfaith purchasers greater rights in the transferred goods than the seller itself had. ${ }^{49}$ This recognizes that buying goods (such as a computer) from a store would be prohibitively expensive if, to protect the purchase, the purchaser had to perform due diligence on whether the store actually owned the computer and whether the computer might be encumbered by any third-party rights. Similarly, to facilitate the transferability of negotiable instruments that substitute for money, such as promissory notes, the UCC gives holders in due course (essentially, good-faith purchasers of those instruments) ${ }^{50}$ greater rights in the transferred instruments than the seller itself had. ${ }^{51}$ This recognizes that it would be prohibitively expensive to use instruments-just as it would be prohibitively expensive to use money-as a medium of exchange and measure of value if one had to perform due diligence on whether the transferor actually owned the instrument (or the money, as the case may be) and whether the instrument (or the money) might be encumbered by any third-party rights or subject to any defenses. ${ }^{52}$

\section{Explaining Why Commercial Law Should Override Property Law to EMpower the PoOr}

Commercial law thus recognizes important policy goals and commercial realities as bases for overriding property-law limitations. By that measure, commercial law should also override those limitations to enable the economically disadvantaged to pledge de facto rights in their homes and other assets as collateral to obtain credit. The ability to pledge those rights would achieve an important policy goal: "unlocking the entrepreneurial potential of billions of people." ${ }^{3}$ It also would facilitate an important commercial reality: allowing de facto rights holders to gainfully use property that de jure owners are not using (and do not intend to use). ${ }^{54}$

There is, however, another justification for enabling the economically disadvantaged to pledge de facto rights in their homes and other assets as collateral $^{55}$ : de facto rights are real rights, though not formally recognized. ${ }^{56}$

49 See infra notes 68-69 and accompanying text (discussing holders in due course of instruments and buyers in ordinary course of goods).

50 See infra note 69.

51 See infra note 69 and accompanying text.

52 See also Shyamkrishna Balganesh, Copyright and Good Faith Purchasers, 104 CALIF. L. REv. 269, 279 (2016) ("American courts, it would appear, came to recognize the undue burden that a rule of no title would place on good faith purchasers by relegating to them the costs of investigating title during each transaction, thereby impeding the efficient functioning of markets.”).

53 Arsenault, supra note 9.

54 I restrict this Article's application to property as to which the de jure owners fail to provide clear notice to preserve their rights. See infra note 92 and accompanying text; see also infra Annex, Model Law art. 4(3).

55 Yet another justification for overriding property law is that the law should correct market failures. See, e.g., Paul A. Samullson \& William D. Nordhaus, Economics 756 
Property law nonetheless implicitly recognizes de facto rights through its view of property as a "bundle of entitlements regulating relations among persons concerning a valued resource." 57 This bundle-of-entitlements-sometimes called a bundle-of-sticks-conception of property law reveals that a property right can be more complex than simple "ownership" of property.

For example, rights in property may include the right to use, the right to exclude use, and the right to transfer, ${ }^{58}$ and different persons can have different rights in the same property. ${ }^{59}$ The economically disadvantaged often have the right to use the property where they live and, arguably, also to exclude use of that property by others. ${ }^{60}$ These rights are de facto because they are respected in practice but not formally under (official) law. ${ }^{61}$ The economically disadvantaged also have the de facto right to transfer their use and exclusion rights, at least to family members such as children. ${ }^{62}$

In order to turn these de facto rights into collateralized credit, the economically disadvantaged would also need to be able to transfer security interests in that property to lenders as collateral for loans. Given their de facto

(15th ed. 1995). Property law itself arguably creates a market failure by enabling the de jure owner to abandon using the property commercially while preventing the de facto right holder from using it.

56 Professor Paulus observes that, in medieval times, jurists already recognized a distinction between de jure rights, called dominium directum, and de facto rights, called dominium utile. See E-mail from Christoph Paulus, Professor of Law, Humboldt Univ. of Berlin, to Steven L. Schwarcz, Stanley A. Star Professor of Law \& Bus. Duke Univ. Sch. of Law (Apr. 20, 2018) (on file with author).

57 Anna di Robilant, Property: A Bundle of Sticks or a Tree?, 66 VAND. L. Rev. 869, 871 (2013).

58 See Joseph William Singer et al., Property Law: Rules, Policies, and Practices, at xxxiv (7th ed. 2017).

59 See id. at 665. For example, person $A$ may have title to Blackacre. Through an easement, person $B$ may gain the right to use person $A$ 's land, while not having the right to exclude $A$ or even a stranger, person $C$. To that extent, person $B$ has a "real" property right. See id. at 534 (describing a nonexclusive easement in which a grantor has reserved the right to use the easement in conjunction with the grantee, as well as the ability to sell further rights to others).

60 See, e.g., Klaus Deininger, Land Policies For Growth and Poverty Reduction 52 (2003) (citing Botswana as a country where individuals have the right to exclude others from land even though formal title is held by the state or community); Bui Quoc Toan et al., Vietnam: Customary Land Tenure Study 9 (World Bank, Working Paper No. 37417, 2004), http://documents.worldbank.org/curated/en/855721468174546190/Vietnam-customaryland-tenure-study (observing that de facto land owners in Vietnam have a restricted right to exclude others).

61 See Legal English: "De Facto/De Jure," supra note 16 and accompanying text (defining de facto rights).

62 See Công Báo Nos 1011-1012 [Land Law], No. 45/2013/QH13 (Dec. 31, 2013), http://extwprlegs1.fao.org/docs/pdf/vie167592.pdf (describing the ability to transfer and inherit land-use rights in Vietnam); DeInINGER, supra note 60, at 31 (noting that most customary systems have inheritable rights to cropland); LANEY ZHANG, LAw Library OF CoNgress, China: Real Property Law 4 (2015) (describing the ability to transfer land-use rights in China). 
right to transfer their use and exclusion rights to related parties, ${ }^{63}$ enabling the economically disadvantaged to transfer security interests in those rights to obtain credit should be a trivial additional step-certainly justified by its benefits. ${ }^{64}$

However, lenders almost certainly would require another step that is far from trivial: transferring a security interest in the underlying de jure rights in the property. This reflects the practical reality that they are unlikely to extend credit unless, in a foreclosure, they can obtain the full rights-both de facto and de jure-in the property pledged as collateral. ${ }^{65}$

This poses a puzzle: a borrower that has only de facto rights in that property cannot normally pledge greater rights. This reflects the longstanding property-law principle of " nemo dat" 66 - the concept that one cannot transfer more rights than one owns. How could holders of de facto rights also transfer the de jure rights?

This Article next attempts to solve that puzzle, examining when commercial law should modify property law's nemo dat restriction. Thereafter, this Article addresses other questions that would be raised by turning de facto rights into collateralized credit, including whether recognizing de facto rights would be unfair to holders of de jure rights, whether the de facto rights could be clearly identified, and-assuming satisfactory answers to the foregoing questions-whether lenders would be prepared to extend, and the economically disadvantaged would be prepared to accept, credit.

\section{A. How Could Holders of De Facto Rights Transfer More Rights than They Hold?}

Commercial law already addresses this conundrum. To facilitate the sale of goods, commercial law gives buyers of goods, in the ordinary course of business, ${ }^{67}$ full unencumbered rights to those goods. ${ }^{68}$ Similarly, to facilitate

63 See supra note 62 and accompanying text.

64 See supra notes 53-54 and accompanying text (discussing these benefits).

65 Absent foreclosure, ownership of the underlying de jure rights in the property would be unaffected because the security interest terminates once the loan is repaid. See U.C.C \$ 9-513 (Am. LAW Inst. \& UNIF. LAw Comm’N 2018) (requiring the secured party to file public notice that its security interest has terminated once the underlying obligation has been satisfied). Even in a foreclosure, the owner of those underlying de jure rights would retain any surplus value in the property not needed to repay the lender. See id. § 9$615(d)(1)$ (providing for the return of such surplus value to the property owner).

66 The phrase, more precisely, is nemo dat quod non habet. There is also a parallel phrase, nemo plus iuris transferre potest quam ipse habet (no one can transfer more rights than he himself has).

67 A buyer of goods in the ordinary course of business is conceptually similar to a holder in due course of negotiable instruments. Both effectively include a person who purchases goods, or receives the transfer of such an instrument, for value, in good faith, and without knowledge that the purchase or transfer violates the rights of another person. Compare id. $\$ 1-201(9)$ (defining buyer in ordinary course), with id. § 3-302(a) (defining holder in due course).

68 See, e.g., id. $\$ 9-320$ (providing that a buyer of goods in ordinary course of business takes free of a security interest created by the seller of the goods, even if the buyer knows of 
the transferability of negotiable instruments, commercial law gives holders in due course full unencumbered rights to these transferred instruments. ${ }^{69}$ If commercial law did not override property law in these ways, the transaction costs of selling goods and negotiating instruments would be prohibitive. As mentioned, one could not buy a computer from a store without performing due diligence to ensure the seller's ownership and the absence of third-party encumbrances, ${ }^{70}$ and one could not use instruments as a medium of exchange without performing due diligence on whether the transferor actually owned the instrument and whether the instrument might be encumbered by any third-party rights or subject to any defenses. ${ }^{71}$

These "bona fide purchaser" exceptions from nemo dat epitomize commercial law's recognition of important policy goals and commercial realities as bases for overriding property law's limitations. But should access to collateralized credit justify another exception to nemo dat, enabling the economically disadvantaged to pledge not only their de facto rights but also the underlying de jure rights? In answering this question, one should realize that although nemo dat is a "common sense" rule, ${ }^{72}$ one of the world's leading property-law scholars observes that "[o]ne could imagine all sorts of different rules, based on the relative qualities of [competing parties], to determine who had the better title-their virtue, their need, and so on." ${ }^{73}$ Moreover, in practice, and without any overarching theory, 74 "exceptions to nemo dat apply often, if not most of the time." 75

Taking into account common sense and practicality, this Article proposes the following answer: the critical benefits provided by access to collater-

the security interest's existence); $i d$. $\$ 2-403$ (2) ("Any entrusting of possession of goods to a merchant who deals in goods of that kind gives [the merchant] power to transfer all rights of the entruster to a buyer in ordinary course of business.")

69 See id. § 3-305(b) (providing that the right of a holder in due course to enforce the obligation of a party to pay an instrument is not subject to defenses of the obligor stated in subsection (a) (2) or claims in recoupment stated in subsection (a) (3) against a person other than the holder). Compare id., with supra notes 51-52 and accompanying text.

70 See supra text accompanying notes 49-50.

71 See supra text accompanying notes 50-52.

72 Smith, supra note 47 , at 2120.

$73 I d$. at 2120-21. Smith is the Fessenden Professor of Law at Harvard Law School.

74 See id. at 2122 ("[It] is easier to describe as a set of exceptions to nemo dat than as a set of freestanding rules with a freestanding nemo dat rule alongside them.”).

$75 I d$. at 2121. Professor Kochan similarly describes exceptions to nemo dat as a practical compromise:

Whereas strict adherence to nemo dat might be theorized as the "first-best" solution to fraudulent and recurrent land conveyances and best at adhering to our formalistic tendencies, the realities of property make that solution less than satisfactory and make exceptions justifiable. We have accepted pragmatically that exceptions must be made and that we may have to, in essence, validate fraud at times.

Donald J. Kochan, Dealing with Dirty Deeds: Matching Nemo dat Preferences with Property Law Pragmatism, 64 U. Kan. L. REv. 1, 3 (2015). 
alized credit ${ }^{76}$ should justify another exception to nemo dat that would enable the economically disadvantaged to transfer as collateral the underlying de jure rights as well as their de facto rights-if doing so is not unfair to holders of those underlying rights. This Article next examines whether recognition of that transfer would be unfair to holders of those underlying rights.

\section{B. Would Recognition of That Transfer Be Unfair to Holders of De Jure Rights?}

Commercial law constantly grapples with conflicting rights and the need for fairness. Questions of balancing rights and fairness arise when giving holders in due course unencumbered rights to transferred negotiable instruments, and also when giving buyers of goods in the ordinary course of business unencumbered rights to those goods. ${ }^{77}$ The answers to these questions inform how rights and fairness should be balanced in the context of this Article's proposal to recognize de facto rights.

A holder in due course can receive the transfer of an encumbered instrument-even one that is already subject to third-party rights, such as a lien-effectively free and clear of the encumbrance. ${ }^{78}$ The implicit fairness rationale is that the party with the original encumbrance could have preserved its rights by providing clear notice of those rights to subsequent transferees. ${ }^{79}$ Similarly, a buyer of goods in the ordinary course of business can purchase the goods free and clear of an existing encumbrance and can even purchase full title to goods from a seller with only limited title. ${ }^{80}$ Again, the implicit fairness rationale is that the party with the original encumbrance or title could have preserved its rights by providing clear notice of those rights to subsequent transferees. ${ }^{81}$

76 These benefits include unlocking the entrepreneurial potential of billions of people, see supra note 53 and accompanying text, recognizing the important commercial reality that the de jure owner is not using the property whereas the economically disadvantaged may be motivated to use it, see supra notes 53-57 and accompanying text, and more generally reducing poverty and facilitating upward mobility.

77 See supra notes 68-69 and accompanying text.

78 See U.C.C. \$ 9-330(d) (Am. Law Inst. \& Unif. Law Comm’n 2018) (providing that such a transferee of an instrument "has priority over a security interest in the instrument perfected by a method other than possession").

79 See id. \$9-330 cmt. 7. An additional fairness rationale is that the party with the original encumbrance may also have a claim for losses against the transferor. See, e.g., Gregory E. Maggs, The Holder in Due Course Doctrine as a Default Rule, 32 GA. L. REv. 783, 786-87 (1998) (arguing that a maker of a promissory note should be able to sue the note's payee for selling defective furniture; instead, the maker had to pay the note in full after it was transferred to a holder in due course). As a rough parallel, this Article suggests giving holders of underlying de jure rights a profit-sharing upside potential in the business started by the borrower. See infra note 91 .

80 See supra note 68 and accompanying text.

81 The Official Comments to UCC $\$ 9-320$ clarify, for example, that a buyer purchases goods subject to a security interest if the buyer is informed that its purchase is intended to be so encumbered. U.C.C. $\$ 9-320 \mathrm{cmt}$. 3. And if a buyer purchasing goods entrusted to a merchant is informed that the merchant's right to sell the goods is limited, the buyer would not be a "buyer in the ordinary course" for purposes of UCC $§ 2-403$. Id. $§ 2-403(2)$. 
Providing clear notice to preserve original rights also has precedent in the somewhat parallel tension between the de jure rights of landowners and the de facto rights of squatters. In many jurisdictions, squatters can ultimately obtain superior rights over the land they occupy under the law of adverse possession. ${ }^{82}$ Having its roots in the English common-law rule of disseisin, adverse possession enables a trespasser to acquire imperfect possessory rights that could, over time, become perfect legal title if the trespasser's use of the land is "open and notorious" 83 and the owner does not act to prevent the trespasser. ${ }^{84}$

The requirements that the trespasser's use of the land be open and notorious and that the owner does not act to prevent the trespasser are grounded in reality. The "open and notorious" requirement takes into account not only whether the trespasser's use is effectively permanent (such as living long-term in a home, as opposed to occasionally picking berries) but also whether such use effectively provides reasonable notice to the owner, enabling the owner to object before losing its land. ${ }^{85}$ Courts also consider who the community believes owns the land. ${ }^{86}$ The owner-does-not-act requirement enables an owner to preserve its rights by providing explicit notifications, such as posting "no trespassing" signs, locking doors, and blocking entry to the land. ${ }^{87}$

Because an additional fairness rationale is that the party with the original encumbrance or title encumbrance may also have a claim for losses against the seller of the goods, this Article again suggests, as a rough parallel, giving holders of underlying de jure rights a profit-sharing upside potential. Compare supra note 79 (describing the fairness rationale that the party with the original encumbrance can recover losses against the transferor), with infra note 91 (suggesting holders of the underlying de jure rights could have the right to receive a specified percentage of profits, for a specified period, from the business started by the de facto owner).

82 See Eduardo Moisés Peñalver \& Sonia K. Katyal, Property Outlaws: How Squatters, Pirates, and Protesters Improve the Law of Ownership 60-61 (2010) (explaining how adverse possession, among other laws, has been used to give squatters formal property rights over absentee owners); see also SINGER ET AL., supra note 58, at 104 (observing that the government often granted formal property rights in the United States to individuals squatting on public land). But cf. id. at 309 (discussing recently passed state statutes restricting adverse possession).

83 Singer ET AL., supra note 58, at 294. In the United States, adverse possession law is state law, not federal law. The majority of U.S. states require a trespasser to prove with clear and convincing evidence (1) "actual possession" for (2) a statutory period (different for each state), that is (3) open and notorious, (4) adverse and hostile, (5) continuous, and (6) exclusive. Id. at 293.

84 See, e.g., Lee J. Alston et al., De Facto and De Jure Property Rights: Land Settlement and Land Conflict on the Australian, Brazilian and U.S. Frontiers 19 (Nat'l Bureau of Econ. Research, Working Paper No. 15264, 2009), http://www.nber.org/papers/w15264 (discussing, among other things, how adverse possession has allowed squatters to transform their occupation into legal title).

85 Singer ET AL., supra note 58, at 294.

86 See id. at 314-15.

87 Id. at 294-96. 
Adverse possession recognizes that a person who has used certain land for a long time may have settled expectations, and that the de jure landowner may have forgotten about or essentially abandoned the land. ${ }^{88}$ Protecting de jure rights might then give the landowner a windfall and inflict a huge loss on the land user. Adverse possession thus can promote the effective utilization of land and also can reduce transaction costs by preventing litigation over "stale" claims to land, such as a claim by a supposed owner from decades ago. ${ }^{89}$

Applying this same type of approach to collateralized credit should similarly respect fairness ${ }^{90}$ while helping to promote the effective utilization of property. ${ }^{91}$ The original de jure rights holders would be required to provide clear notice to preserve their rights. To avoid doubt and protect de facto rights holders, any such notice should be physically obvious and manifestly clear. It might include, for example, posting "no trespassing" signs, locking doors, and/or blocking entry or access to property. ${ }^{92}$ It should not include

88 Id. at $313-15$.

89 See id. at 310-11.

90 Cf. Kochan, supra note 75, at 4, 52-60 (advocating an "inquiry notice" approach to give original owners "additional opportunities to protect their title interests"). A legal process that respects fairness while promoting the effective utilization of property should also be respected under laws that protect private property. For example, Protocol 1 to the European Convention on Human Rights states:

Every natural or legal person is entitled to the peaceful enjoyment of his possessions. No one shall be deprived of his possessions except in the public interest and subject to the conditions provided for by law and by the general principles of international law.

The preceding provisions shall not, however, in any way impair the right of a State to enforce such laws as it deems necessary to control the use of property in accordance with the general interest ....

Eur. Conv. on Human Rights, Protocol to the Convention for the Protection of Human Rights and Fundamental Freedoms, art. 1, Mar. 20, 1952, C.E.T.S. 009 (protection of property).

91 To help balance the risk that they could lose their rights in a foreclosure, holders of the underlying de jure rights could receive a profit-sharing upside potential in the business started by the borrower, such as the right to receive a specified percentage of profits, for a specified period, from the business started by the de facto owner. A profit-sharing upside would also be consistent with the concept of corrective justice, which requires a person to repair losses that his conduct causes even if the person is not morally to blame for the losses. Theories of the Common Law of Torts, Stan. Encyclopedia Phil. \$ 3.1, https:// plato.stanford.edu/entries/tort-theories/\#CorJus (last updated Dec. 17, 2015) (discussing corrective justice theory); cf. Christopher H. Schroeder, Corrective Justice and Liability for Increasing Risks, 37 UCLA L. REv. 439, 439 (1990) (arguing that ideal corrective justice should not be subject to a causation requirement; a person who increases the risk of harm occurring should be liable, period).

92 See infra Annex, Model Law art. 4(3) (enabling de jure rights holders to provide clear notice to preserve their rights). Compare infra Annex, Model Law art. 3(2) (defining "clear notice"), with supra note 87 and accompanying text (discussing clear notice in the context of adverse possession law). 
notices posted by mail or distributed electronically or through the media. ${ }^{93}$ Furthermore, no such notice should impair the right of economically disadvantaged persons to continue living on or using property. ${ }^{94}$

One might question whether allowing de jure rights holders to give clear notice to preserve their rights could effectively prevent the disadvantaged from obtaining credit: Wouldn't reasonable de jure rights holders always give such notice, thereby preventing foreclosure on their property (and thus effectively preventing it from being used as collateral)? In answer, relatively few de jure rights holders likely know of their rights; it is unclear who, other than the government, ${ }^{95}$ owns much of the property in which the disadvantaged hold de facto rights. ${ }^{96}$

That itself raises the question of whether it is fair to impair property rights of persons who are unaware they hold such rights. At least in partial answer, the law has a long tradition of cutting off such rights, epitomized not only by adverse possession law, ${ }^{97}$ but also by escheatment law, which treats property as abandoned if the owner is unknown or cannot be located. ${ }^{98}$ Furthermore, the government itself appears to own a significant portion of the

93 The clear-notice requirement raises a practical problem that could be caused by physical deterioration of the notice or even by economically disadvantaged persons intentionally removing signs, unlocking doors, or otherwise unblocking entry or access to property prior to granting a security interest. To attempt to balance interests, Article 4(3) of the Model Law provides, in part, that the grant of a security interest in de facto rights shall not include a security interest in the underlying de jure rights if, at any time within the ninety-day period prior to the grant of a security interest in such de facto rights, there exists clear notice of the intent of the owner of the underlying de jure rights to preserve such de jure rights. Infra Annex, Model Law art. 4(3). Thus, if a "no trespassing" sign blows away or is removed thirty days prior to the grant of a security interest in such de facto rights, the owner of the underlying de jure rights remains protected. But if a "no trespassing" sign blows away or is removed ninety-one days prior to the grant of a security interest in such de facto rights, the security interest also attaches to the underlying de jure rights. The owner of the underlying de jure rights could protect those rights by monitoring the property at least every ninety days.

94 See infra Annex, Model Law art. 4(4) (providing that notices shall not otherwise impair de facto rights).

95 See infra note 99 and accompanying text.

96 See Why Secure Land Rights Matter, supra note 13 (referencing a World Bank study discussing the uncertainties associated with property rights); $c f$. Borrows, supra note 15 , at 100 (discussing the uncertainty surrounding aboriginal title and property rights in Canada); Martin E. Gold \& Russell B. Zuckerman, Indonesian Land Rights and Development, 28 Colum. J. Asian L. 41, 47, 53-56 (2014) (finding that the majority of land in Indonesia is not formally registered); Honduras, USAID, https://land-links.org/country-profile/honduras/\#land (last updated Apr. 2011) ("Approximately $80 \%$ of the privately held land in the country is untitled or improperly titled. Only $14 \%$ of Hondurans legally occupy properties and, of the properties held legally, only $30 \%$ are registered.").

97 See supra notes 88-89 and accompanying text (discussing adverse possession law, which recognizes that the de jure landowner may have forgotten about or essentially abandoned the land and also seeks to prevent litigation over stale claims).

98 See, e.g., 30A C.J.S. Escheat $\S 12$ (2007). 
property in which the disadvantaged hold de facto rights. ${ }^{99}$ To that extent, the question of fairness would be less critical, devolving instead into a political issue. This Article suggests that the government should subordinate its de jure rights to the rights of the economically disadvantaged. ${ }^{100}$

One also might ask whether an alternative to this Article's proposal should be to extend adverse possession law more widely. ${ }^{101}$ Adverse possession law, however, is much more onerous to de jure rights holders because it deprives them of title outright, not merely in the event of a lender foreclosure. ${ }^{102}$ Moreover, unlike adverse possession, this Article's proposal encourages, and indeed is effectively conditioned on, ${ }^{103}$ the economically disadvantaged borrowing to start small businesses, ${ }^{104}$ which would bring important economic and social benefits. ${ }^{105}$ Extending adverse possession law would therefore be a poor alternative.

99 See, e.g., Liz Alden Wily, Rights to Resources in Crisis: Reviewing the Fate of Customary Tenure in Africa, Brief \#1 of 5, in Customary Land Tenure in the Modern World: Rights TO Resources IN CRIsIs 1 (2011), http://rightsandresources.org/wp-content/uploads/ RightsToResourcesInCrisis.Compiled_ENGLISH.pdf. Wily finds that the landholding status of forests, rangelands, marshlands, and other uncultivated lands in Africa is often regarded by the government "as un-owned public lands or state property." Id. She also finds that this type of landholding status represents a "major tenure system on a worldwide scale" and "is not confined to Africa." Id. at 2; cf. Holding Their Ground: Secure Land Tenure for the Urban Poor in Developing Countries 18 (Alain Durand-Lasserve \& Lauren Royston eds., 2002) ("In a large number of sub-Saharan African countries . . the land is owned and managed by the state .....); Robin Mearns, Access to Land in Rural India: Policy Issues and Options 27 (World Bank, Policy Research Working Paper No. 2123, 1999) ("In rural India, some of the most important village commons include community forests, pasture or 'wasteland', river banks, river beds, ponds and tanks. Forest department land may also form de facto commons, whether or not local inhabitants have legal rights to its products. In total, commons may account for around 20 percent of India's total land area.").

100 See infra Annex, Model Law arts. 4(2)-(3), 8 (providing that government-owned property is subject to foreclosure).

101 Several commentators have asked this question. See, e.g., Sally Brown Richardson, Abandonment and Adverse Possession, 52 Hous. L. Rev. 1385, 1385-86 (2015).

102 See supra note 65 (observing that, absent foreclosure, ownership of the underlying de jure rights in the property would be unaffected because the security interest terminates once the loan is repaid; and that even in a foreclosure, the owner of those underlying de jure rights would retain any surplus value in the property not needed to repay the lender).

103 See infra note 137 and accompanying text (observing that although this Article generally contemplates that loan proceeds be used to start a small business, the Model Law does not strictly mandate that use; this flexibility recognizes that prudent borrowers will want to use the loan proceeds to generate wealth and prudent lenders will condition lending on that use).

104 There are other differences, possibly less significant. For example, adverse possession law applies primarily to real estate. Also, this Article's proposal, unlike adverse possession, contemplates the possibility of profit sharing. See supra note 91 and accompanying text.

105 See infra notes $179-80$ and accompanying text. 


\section{How Could the De Facto Rights Be Clearly Identified?}

This question is perhaps the most difficult in practice. To satisfy lenders and create credit, commercial law must clearly define and identify de facto rights in collateral. However, existing real estate recording systems identify only de jure rights, and they tend to use metes and bounds or other parameters for identification that might not always be practical for describing de facto rights. ${ }^{106}$

De Soto addressed this question by arguing that economically disadvantaged people have developed their own ways of determining who owns what, as part of "extralegal social contracts," and that any reform should be based on-or at least rooted in-these behavioral norms and customs. ${ }^{107}$ When traveling through Indonesian rice paddies, he observed to government officials that there was no clear way of knowing where one farmer's land ended and another's began, but "the dogs knew." 108 "Every time [he] crossed from one farm to another, a different dog barked. Those Indonesian dogs may have been ignorant of formal law, but they were positive about which assets their masters controlled," and thus "[b]y traveling their city streets . . . and listening to the barking dogs, [the officials] could gradually work upward . . . until they made contact with the ruling social contract." 109

One of the Indonesian officials characterized this as "Jukum Adat," the people's law. ${ }^{110}$ A people's-law approach actually has strong commercial-law precedent. For example, UCC $\S 1-303$ recognizes course of performance ${ }^{111}$ and course of dealing. ${ }^{112}$ "A course of performance or course of dealing between the parties ... is relevant in ascertaining the meaning of the parties'

106 See, e.g., Singer ET AL., supra note 58, at 950-51 (describing three methods used to identify real property boundaries in deeds: metes and bounds, government surveys, and plats); David C. Ling \& Wayne R. Archer, Real Estate Principles: A Value Approach 59-65 (4th ed. 2013) (describing three legal methods used to measure property boundaries: metes and bounds, subdivision plat and block number, and government rectangular survey). Metes measures land by indicating the distance (and sometimes the compass bearing) between specified points. $I d$. at 59 . Bounds measures land by its position relative to known landmarks, such as streams, walls, or roads. Id.; see also WALter G. Robillard \& Donald A. Wilson, Brown's Boundary Control and Legal Principles 86-94 (7th ed. 2014).

107 DE Soto, supra note 5, at 134-41.

$108 I d$. at 128.

$109 I d$.

$110 I d$.

111 A "course of performance" is a "sequence of conduct between the parties to a particular transaction that exists if" the following are true:

(1) the agreement of the parties with respect to the transaction involves repeated occasions for performance by a party; and

(2) the other party, with knowledge of the nature of the performance and opportunity for objection to it, accepts the performance or acquiesces in it without objection.

U.C.C. § 1-303(a) (Am. LAw Inst. \& UnIf. LAw Comm'N 2018).

112 A "course of dealing" is a "sequence of conduct concerning previous transactions between the parties to a particular transaction that is fairly to be regarded as establishing a 
agreement, may give particular meaning to specific terms of the agreement, and may supplement or qualify the terms of the agreement." 113

The practical problem, though, is that a people's-law or similar approach might not sufficiently identify the collateral to satisfy lenders. The challenge is to adequately identify the collateral without generating prohibitively high transaction costs. Technology affords at least one way to accomplish that. Either the government, a nongovernmental organization (NGO), or in some cases perhaps a local neighborhood association could organize the residents to allocate their de facto property rights by setting flags or other visible markers at the boundaries. ${ }^{114}$ Satellite, drone, or other overhead imagery could then document that for translation into an accurate and easily ascertainable description of those allocated boundaries. ${ }^{115}$ The law would respect that allocation if it followed a prescribed methodology, ${ }^{116}$ which-for the reasons discussed below ${ }^{117}$ —need not conform to the jurisdiction's existing mortgage-recording system. ${ }^{118}$ The allocation would be transcribed to a government record that lenders could search. ${ }^{119}$

The commercial-law distinction between the clarity needed to create a security interest and the clarity needed to perfect that interest helps to explain why this approach would provide sufficient clarity at low transaction costs. Creating a security interest requires a reasonably identifiable description of the collateral because it effects the transfer of that interest from a

common basis of understanding for interpreting their expressions and other conduct." Id. $\S 1-303(\mathrm{~b})$.

113 Id. $\$ 1-303(\mathrm{~d})$.

114 See Trebilcock \& Veel, supra note 19, at 457-58 (noting that the Republic of Cameroon's title process involved state agents placing concrete boundary markers on farmers' land).

115 This might be done, for example, using GPS. See Victor Neene \& Monde Kabemba, Development of a Mobile GIS Property Mapping Application Using Mobile Cloud Computing, 8 INT'L J. Advanced Computer Sci. \& Applications 57, 57-65 (2017) (providing examples of using current technologies to map properties and explaining how to develop and use a mobile property mapping application). The costs associated with doing this could be borne by governments or NGOs or collectively by local communities. Although it is a political issue, some developed nations that maintain satellites might be willing to absorb the cost of satellite imagery.

116 See, e.g., infra Annex, Model Law art. 5(2)-(3) (discussing reasonable methods for describing collateral).

117 See infra notes 121-30 and accompanying text.

118 Any disagreement about a boundary between de facto rights could be resolved at the local level. See, e.g., Gold \& Zuckerman, supra note 96, at 61 (observing that the majority of land disputes in Indonesia are resolved locally by the village head, who applies custom as modified by Sharia law); Mastewal Yami \& Katherine A. Snyder, After All, Land Belongs to the State: Examining the Benefits of Land Registration for Smallholders in Ethiopia, 27 Land Degradation \& Dev. 465, 473-74 (2016) (observing that complaint-handling committees, village elders, and religious leaders work together in Ethiopia to resolve disputes over land boundaries that cannot be resolved by land administration officials).

119 See infra Annex, Model Law art. 5(4) (respecting allocations that follow prescribed methodologies). 
debtor to a secured creditor. ${ }^{120}$ This Article's approach reasonably identifies the collateral in two steps: first, recognizing the de facto rights collectively; second, recognizing an allocation of those rights that follows the relevant prescribed methodology. ${ }^{121}$

That methodology need not conform to the jurisdiction's existing mortgage-recording system. The primary purpose of a mortgage-recording system is to give notice to third parties, not necessarily to allocate rights between a debtor (mortgagor) and secured creditor (mortgagee). ${ }^{122}$ Whether the collateral is real estate or personal property, the debtor and secured creditor need only clearly identify the collateral as between themselves. ${ }^{123}$

Much less clarity is needed, in contrast, to perfect a security interest-a step often required under law to put third parties on notice that property may be encumbered as collateral. ${ }^{124}$ For real estate, perfection normally involves describing the collateral in a mortgage-recording system. ${ }^{125}$ Although mortgage-recording descriptions often specifically identify the collateral by official government surveys or metes and bounds, ${ }^{126}$ the description need not be that specific. Because the agreement creating the security interest provides the specificity, ${ }^{127}$ perfection only requires notice to third parties that property might be subject to a security interest. ${ }^{128}$ A description

120 See U.C.C. § 9-108(a) (Am. Law Inst. \& UnIF. Law Comm'N 2018) (“[A] description of personal or real property is sufficient, whether or not it is specific, if it reasonably identifies what is described."). This description is normally included in the security agreement that creates the security interest. See id. \$9-201(a) ("[A] security agreement is effective according to its terms between the parties ....").

121 See supra notes $116-17$ and accompanying text.

122 Cf. Singer ET AL., supra note 58, at 995-96 (explaining that lenders use mortgagerecording systems "to understand and give notice to others of their security interest in the property").

123 Dale A. Whitman, What You Didn't Know About Real Estate Recording Acts, ABA SECtion Real Prop. Tr. \& Est. L. eReport (Nov. 9, 2016), https://www.americanbar.org/ content/dam/aba/publications/rpte_ereport/2016\%20eReport/6-November\%202016/

What\%20You\%20Didn_t\%20Know\%20about\%20Recording\%20Acts_Whitman\%20(2) .pdf.

124 The rationale for perfection is that notice avoids misleading third parties. Amy Loftsgordon, What Does It Mean to Perfect a Lien?, NoLO, https://www.nolo.com/legal-encyclopedia/what-does-mean-perfect-lien.html (last visited Jun. 5, 2018) (stating that the recording required to perfect a mortgage serves to give other parties notice of the lien). An encumbrance on property that is not disclosed is often condemned as a "secret lien." Michael Simkovic, Secret Liens and the Financial Crisis of 2008, 83 Aм. Bankr. L.J. 253, 256 (2009).

125 See Lori Anne Czepiel et al., Lending and Taking Security in the United States: Overview, ThOMSON Reuters, https://uk.practicallaw.thomsonreuters.com/9-501-2871?transitionType $=$ Default\&contextData $=($ Sc.Default $) \&$ firstPage $=$ true $\& b h c p=1 \quad$ (last updated Mar. 1, 2018).

126 See supra note 106 and accompanying text.

127 See supra notes 120-23 and accompanying text.

128 See, e.g., John Mirkovic, Blockchain Pilot Program Final Report 9, 21 (2017), http://cookrecorder.com/wp-content/uploads/2016/11/Final-Report-CCRD-BlockchainPilot-Program-for-web.pdf ("The State of Illinois does not have a legal requirement that 
of collateral is sufficient for perfection if it merely "provides notice that a person may have a security interest in the collateral claimed." 129 This minimal description requirement reduces transaction costs. ${ }^{130}$

In principle, this approach should enable a lender to perfect its security interest in allocated de facto rights by filing a standard description of the broader de jure rights in the applicable mortgage-recording system. That description might even be a copy of the existing recorded description of those rights. ${ }^{131}$ It would not need to actually redescribe those allocated rights using metes and bounds or other mortgage-recording parameters. ${ }^{132}$

\section{Would Lenders Be Prepared to Extend Credit?}

Assuming satisfactory answers to the foregoing questions, would banks and other lenders actually extend credit to economically disadvantaged borrowers, based primarily on collateral? Being a practical question, this can only be answered empirically based on what lenders actually do. ${ }^{133}$ Nonetheless, the following observations may inform the answer.

deeds and conveyancing instruments be recorded in a Recorder's Office and, thus, recording a deed does not increase or enhance the validity of the conveyance. . . The ultimate purpose of recording an instrument is not to validate the conveyance or make the conveyance 'more legal,' but instead is to provide notice . . ..")

129 U.C.C. $\$ 9-504$ cmt. 2 (Ам. Law Inst. \& UnIf. Law Comm’n 2018). For that reason, a financing statement is sufficient to describe the collateral if it simply provides an indication that it covers "all assets or all personal property." Id. §9-504(2). Compare id. §9308(a) (providing that "a security interest is perfected if it has attached and all of the applicable requirements for perfection in Sections 9-310 through 9-316 have been satisfied"), with id. $\$ 9-310$ (a) (stating the general rule that "a financing statement must be filed to perfect all security interests").

130 Other provisions of the Uniform Commercial Code also work to reduce transaction costs. See, e.g., id. \$ 9-310(c) ("If a secured party assigns a perfected security interest . . , a filing under this article is not required to continue the perfected status of the security interest against creditors of and transferees from the original debtor."). The logic is that the original notice filing should be sufficient to inform third parties that the collateral may be encumbered. See also Peter F. Coogan, Public Notice Under the Uniform Commercial Code and Other Recent Chattel Security Laws, Including "Notice Filing," 47 IowA L. Rev. 289, 293 (1962) ("If the easier methods of [notice] filing are intelligently used, the [Uniform Commercial] Code will make a great contribution toward simplifying security transactions.").

131 See infra Annex, Model Law art. 7(2) (allowing that description).

132 Adverse possession law similarly resolves conflicts between de facto owners by using criteria other than metes and bounds. See, e.g., J.W. Harris, Property and Justice 82-83 (1996) (explaining that "squatter 1" must have openly acted as the owner to succeed in a land claim over "squatter 2"); H.L. Burgoyne, Title by Adverse Possession, 6 LAw. \& BANker \& S. BENCH \& B. Rev. 197, 199-200 (1913) (explaining that the element of actual possession in a claim for adverse possession is typically determined by evidence of ownership in relation to the disputed land, such as residence on the land, the erection of buildings, or fencing, clearing, or cultivating the land).

133 I later examine potentially informative empirical data on how property-titling programs affect the willingness of banks to extend credit to economically disadvantaged borrowers. See infra notes 155-67 and accompanying text. 
Bank lending traditionally has focused on "two ways out," such as asset value and cash flow, as dual means of repaying the loan. ${ }^{134}$ With the resurgence of leveraged buyouts (LBOs) and other leveraged acquisition-of-control financing, banks have sometimes shifted their focus more on asset value as the repayment source. ${ }^{135}$ The key is that the loans be sufficiently overcollateralized-that their collateral value exceed the amount of the loan by a reasonable margin, enabling repayment in the event of a default. ${ }^{136}$

This Article's concept of extending credit to economically disadvantaged borrowers would follow that pattern: the lenders would look primarily to the collateral. Although their potential second way out would be the profits of small businesses started with the proceeds of their loans, ${ }^{137}$ small business start-ups have a high failure rate. ${ }^{138}$ Prudent lenders therefore would insist, as indicated above, ${ }^{139}$ that their loans be sufficiently overcollateralized. ${ }^{140}$

Abuses leading up to the global financial crisis of 2007-08 have created uncertainty, however, for asset-based lending to economically disadvantaged borrowers. Lenders made massive amounts of so-called "subprime" mortgage

134 Cf. Mark Carey et al., Does Corporate Lending by Banks and Finance Companies Differ? Evidence on Specialization in Private Debt Contracting, 53 J. FIN. 845, 850-51, 851 n.2 (1998) (observing that banks can be asset-based lenders and cash-flow-based lenders); Lynn M. LoPucki, The Unsecured Creditor's Bargain, 80 VA. L. REv. 1887, 1924-47 (1994) (recognizing two types of unsecured lending: asset-based unsecured lending and cash-flow-based unsecured lending).

135 See, e.g., Appendix H-Glossary, Fed. Banking L. Rep., 2015 WL 6277290 (observing that for loans made to finance "takeovers, leveraged buyouts and restructurings," "[a]ssurance of interest and principal payments in the future is limited; repayment often depends on asset sales rather than the ongoing profitability of the business"). Lending for breakup or bust-up LBOs depends almost entirely on the target company's sales of its assets for repayment. See Kevin J. Liss, Note, Fraudulent Conveyance Law and Leveraged Buyouts, 87 Colum. L. Rev. 1491, 1493 (1987).

136 Steven L. Schwarcz, Regulating Complacency: Human Limitations and Legal Efficacy, 93 Notre DAme L. Rev. 1073, 1093 (2018) (“'[L]oans that are not initially overcollateralized are inherently risky, given that a decline (or even a plateau) in collateral' value could jeopardize repayment." (quoting Steven L. Schwarcz \& Lucy Chang, Essay, The Custom-toFailure Cycle, 62 Duke L.J. 767, 784 (2012))). In the context of pledging de facto rights as collateral, prudent lending would require the value of that collateral to exceed the amount of the loan by some reasonable margin.

137 The Model Law does not mandate that the loan proceeds must be used to start a small business. Although this Article generally contemplates that use, omitting such a mandate gives borrowers and lenders case-by-case flexibility to negotiate how loan proceeds could be used-implicitly trusting that prudent borrowers will want to use the proceeds to generate wealth and that prudent lenders will condition lending on that use. As appropriate, a lender always has the right to include a use-of-proceeds clause requiring a specific use of the loan proceeds.

138 See infra note 183.

139 See supra note 136 and accompanying text.

140 A prudent lender also would want to document that the borrower is economically disadvantaged at the time of making the loan, to ensure that the security interest in the underlying de jure rights is enforceable. Article 4(5) of the Model Law provides a safe harbor for this determination. See infra Annex, Model Law art. 4(5). 
loans to such borrowers, depending entirely on the expectation of housingprice appreciation-and subsequent refinancing-for repayment. ${ }^{141}$ Many of the world's most sophisticated financial institutions invested billions of dollars in mortgage-backed securities that were payable from collections on these subprime mortgage loans. ${ }^{142}$ When housing prices failed to appreciate, and in many regions began to depreciate, these lenders and investors suffered huge losses. ${ }^{143}$ As a result, subprime asset-based loans are perceived as inherently risky. ${ }^{144}$

In reality, though, whether subprime asset-based loans are actually risky depends on the extent of overcollateralization. Prudent asset-based lending should never have to depend-as subprime mortgage lenders depended prior to the financial crisis ${ }^{145}$ - on the expectation of collateral appreciation for overcollateralization. Instead, prudent subprime asset-based loans should be adequately overcollateralized when they are made. ${ }^{146}$ In contrast to precrisis subprime mortgage lending, this Article's vision of extending credit should meet that prudence standard.

The reason why precrisis subprime mortgage lending failed that standard-whereas extending credit to economically disadvantaged borrowers secured by their de facto rights should meet it-turns on basic principles of purchase-money lending. A subprime mortgage loan is a type of purchasemoney loan in which a lender advances funds to an economically disadvantaged borrower to purchase a home and pledges the home as collateral for the loan. ${ }^{147}$ Because economically disadvantaged borrowers rarely have money to make a down payment, the amount of the loan usually must equal

141 Fin. Crisis Inquiry Comm'n, The Financial Crisis Inquiry Report: Final Report of the National Commission on the Causes of the Financial and Economic Crisis in the United States 165 (2011) (stating that many of the subprime mortgage products "would perform only if [housing] prices continued to rise and the borrower could refinance at a low rate").

142 See id. at xvi ("When the [housing] bubble burst, hundreds of billions of dollars in losses in mortgages and mortgage-related securities shook markets as well as financial institutions that had significant exposures to those mortgages and had borrowed heavily against them.").

143 Id. at 213-15, 227-28.

144 Cf. Singer ET AL., supra note 58, at 968-69 (discussing the federal and state laws passed after the financial crisis to regulate subprime mortgage lending (and thus avoid risky lending practices)).

145 See supra note 141 and accompanying text.

146 See Steven L. Schwarcz, Essay, Protecting Financial Markets: Lessons from the Subprime Mortgage Meltdown, 93 Minn. L. REv. 373, 390 (2008) (explaining why prudent subprime asset-based lending would require a minimum level of overcollateralization).

147 See, e.g., Yuliya Demyanyk \& Otto Van Hemert, Understanding the Subprime Mortgage Crisis, 24 Rev. Fin. Stud. 1848, 1849 (2011); Purchase Money Mortgage, Legal Info. Inst., https://www.law.cornell.edu/wex/purchase_money_mortgage (last visited June 10, 2018) (defining purchase-money mortgage). 
the purchase price of the home. ${ }^{148}$ The loan therefore is not overcollateralized when made; it depends on an expectation of home appreciation for overcollateralization. ${ }^{149}$

In contrast, loans made to economically disadvantaged borrowers secured by their de facto rights, as contemplated by this Article, are not purchase-money loans. The borrower already has those de facto rights. A lender would extend credit based on its valuation of the collateral, with prudent lenders insisting on overcollateralization. To illustrate, say a prospective borrower resides on property valued by the lender at $\$ 100,000$ and would like to borrow $\$ 100,000$. No prudent lender would make such a loan. A lender might counter, however, with an offer to lend $\$ 75,000$ secured by that collateral-providing significant overcollateralization. ${ }^{150}$ The prudent lending standard thus will restrict the relative amount an economically disadvantaged person could borrow against his de facto rights. Nonetheless, that amount may well be sufficient to start a viable small business.

If needed, this Article's proposal for borrowing based on de facto collateral rights could be supplemented to induce lenders to advance higher amounts. For example, some communities might consider providing crossguarantees of repayment, which is typical in microfinance lending. ${ }^{151}$ Those guarantees would constitute a second source of repayment, and thus would justify a higher advance rate. ${ }^{152}$ Governmental or multigovernmental entities might also consider helping to partially or fully guarantee loans in order

148 See, e.g., Megan Elliott, Can't Afford a 20\% Down Payment? 6 Ways You Can Buy a Home, Showbiz CheAt Sheet (Dec. 11, 2017), https://www.cheatsheet.com/moneycareer/cant-afford-20-percent-down-payment-ways-you-can-buy-a-home.html/?a=viewall.

149 See supra note 141 and accompanying text.

150 As an industry custom, mortgage lenders often measure overcollateralization by the loan-to-value ratio (LTV). See, e.g., Charles W. Calomiris \& Joseph R. Mason, High Loanto-Value Mortgage Lending 25 (1999) (noting that collateral, measured by LTV, is one of the "three Cs" critical to mortgage lending). In the example in the text above, the LTV would be seventy-five percent (i.e., $\$ 75,000$ loan divided by $\$ 100,000$ collateral value).

151 See Schwarcz, Disintermediating Avarice, supra note 25, at 1192. Some of the cultural factors that are important for microfinance may also be worth considering. Cf. Kozolchyk, supra note 25, at 737-40 (arguing that credit also depends on having cultural values that recognize a borrower's duties toward his or her creditors).

152 As discussed previously, bank lending generally recognizes two ways of repaying a loan: asset value and cash flow. See supra note 134 and accompanying text (discussing two ways out); $c f$. Meng Miao \& Oren Sussman, Financial Distress, Contract Enforcement and Asset Grabbing: An Investigation of Repossession Reform in China (July 29, 2019) (unpublished manuscript) (on file with author) (discussing the importance of third-party loan guarantees in China, where secured collateral is weak). 
to attract private credit, ${ }^{153}$ or even making loans directly from public resources. ${ }^{154}$

Finally, it can be informative to examine the empirical studies on how property-titling programs affect the willingness of banks to extend credit to economically disadvantaged borrowers. After surveying these studies for the U.S. Agency for International Development, an agricultural economist concluded that " $[\mathrm{w}]$ hile land titling can help to expand access to credit in some circumstances and can be an important part of a poverty reduction strategy," 155 "in most developing world environments, the ability to leverage a title for credit is limited for a variety of reasons." ${ }^{156}$ Because titling programs can inadvertently undermine the willingness to extend credit, ${ }^{157}$ one should interpret that conclusion cautiously. Nonetheless, the "variety of reasons" the survey gives to explain why a titling program may be limited in expanding access to credit can help to inform this Article.

153 Many governmental and multigovernmental organizations have been making these types of guarantees. See, e.g., Guarantees Program, World Bank, http:// www.worldbank.org/en/programs/guarantees-program (last visited Sep. 8, 2019) (stating that an important aim of its Guarantee Program is to "[m]obilize private investment (equity and debt) for strategic projects or sector support"); Medium and Long-Term Loan Guarantee, ЕXPORT-IMPORT BANK U.S., https://www.exim.gov/what-we-do/loan-guarantee (last visited Sep. 8, 2019) (stating that the EXIM Bank provides loan guarantees to help companies "secure competitive financing for [their] international buyers" on competitive terms otherwise unavailable to such buyers); World Bank Guarantees in Action, WORLD BANK (Feb. 9, 2018), http://www.worldbank.org/en/programs/guarantees-program/brief/ world-bank-guarantees-new-project-briefs (detailing "how World Bank guarantees mobilize commercial financing for investment projects, help restructure expensive debt of utilities, and increase developing countries' access to capital markets"); see also RAUNDI HalvorsonQuevedo \& Mariana Mirabile, Org. for Econ. Co-operation \& Dev., Guarantees for DEVELopMENT 2 (2014) ("Developmental guarantees are a valuable instrument for mobilising private resources—be they from private companies, banks, individuals, NGOs, self-help groups, investment funds, etc. For a fraction of the potential cost of the risk exposure undertaken, considerable liquid resources can be deployed for investments to improve economic and social conditions .....").

154 For example, the U.S. government offers several types of direct loans, including small business loans. See Government Grants and Loans, USAGov, https://www.usa.gov/ grants\#item-37017 (last updated Mar. 25, 2019). As appropriate, lenders and guarantors might consider negotiating, as a quid pro quo, some profit sharing with borrowers whose businesses ultimately become successful. See supra note 91 (discussing a profit-sharing upside potential to help balance the risk that holders could lose their underlying de jure rights in a foreclosure).

155 Jolyne Sanjak, U.S. Agency for Int'l Dev., Land Titling and Credit AccessUNDERSTANDING THE REALITY 1, 3 \& n.7 (2012), https://www.land-links.org/wp-content/ uploads/2016/09/Land-Titling-and-Credit-Access-Understanding-the-Reality.pdf (citing research that empirically shows that "titling significantly improved farmer access to credit").

156 Id. at 1.

157 Cf. supra note 22 and accompanying text (arguing that titling programs send the message that governments will side with poor borrowers in enforcing repayment). 
One reason the survey gives is that some of the titling occurred in jurisdictions that lacked private-sector lenders. ${ }^{158}$ To remedy this, governmental or multigovernmental entities should consider extending credit if private-sector sources are unavailable. ${ }^{159}$ This Article's Model Law provides that option. ${ }^{160}$ Another reason given is that the transaction costs of taking collateral to secure relatively small loans can make lending unprofitable. ${ }^{161}$ To remedy this, economically disadvantaged borrowers should have the right to borrow on a joint-and-several basis, pooling their collateral. The Model Law provides this right. ${ }^{162}$ This right would be especially useful, for example, where multiple borrowers join together to collectively start a business. ${ }^{163}$ Yet another reason explaining the limit is possible legal uncertainty whether the titling program adequately grants property rights. ${ }^{164}$ The Model Law would eliminate that uncertainty because it operates by directly granting collateral and foreclosure rights. ${ }^{165}$ The last reason explaining the limit is possible legal uncertainty about the validity and enforceability (including the right to foreclose) of the lenders' security interests in collateral. ${ }^{166}$ Again, the Model

158 See SANJAK, supra note 155, at 6 (discussing studies that attribute limitations of land titling to provide access to credit to the fact that "formal credit . . markets do not exist in the survey area" and to "the scarcity of formal credit sources in the survey areas" (quoting Anne-Sophie Brasselle et al., Land Tenure Security and Investment Incentives: Puzzling Evidence from Burkina Faso, 67 J. Dev. Econ. 373, 400-01 (2002)).

159 See supra notes 153-54 and accompanying text (discussing possible financial assistance from governmental or multigovernmental entities).

160 See infra Annex, Model Law art. 10.

161 See SANJAK, supra note 155, at 2 (observing that "the assets that these households have are too small in value . . making the costs to a lender in doing business with such clients unjustified"). The value of these assets, however, is becoming substantial. See, e.g., Guiliander Carpes, A House in a Favela Can Cost R\$700,000 (US\$313,000), RioONWATcH (Harriet Batey trans., July 18, 2013), http://www.rioonwatch.org/?p=10452; M. Rajshekhar, Great Rural Land Rush: 3 to 100-Fold Rise in Farm Land Prices May Not Bode Well, EcON. Times, https://economictimes.indiatimes.com/news/economy/agriculture/greatrural-land-rush-3-to-100-fold-rise-in-farm-land-prices-may-not-bode-well/articleshow/

25607513.cms (last updated Nov. 12, 2013) (reporting on the skyrocketing price of farmland in rural India).

162 See infra Annex, Model Law art. 4(6).

163 Lending to the poor on a joint-and-several basis has significant precedent in microfinance. See, e.g., Jon Einar Flatnes \& Michael Carter, A Little Skin in the Microfinance Game: Reducing Moral Hazard in Joint Liability Group Lending Through a Mandatory Collateral Requirement 2 (May 25, 2016) (unpublished paper prepared for presentation at the 2016 Agricultural \& Applied Economics Association Annual Meeting), http://ageconsearch.umn.edu/record/236157/files/A_little_skin_in_the_microfinance_ game_-_Flatnes_Carter-AAEA_submission.pdf (observing joint lending's popularity in microfinance).

164 See SANJAK, supra note 155, at 3-6 (observing that land titling alone may be insufficient in some jurisdictions to establish property rights).

165 See infra Annex, Model Law art. 8 (governing foreclosure).

166 See SANJAK, supra note 155, at 7 (discussing studies that find the need for "a legal framework for secured transactions to use those assets as collateral for loans" and also observing possible limits on "pledging or enforcement of pledges upon default"). 
Law would eliminate that uncertainty by directly granting collateral and foreclosure rights. ${ }^{167}$

\section{E. Would the Poor Be Willing to Borrow?}

After struggling to empower the economically disadvantaged with credit, this question may seem anticlimactic. However, people tend to be risk averse. ${ }^{168}$ A person who lives on land (or otherwise uses property) may be unwilling to risk losing it in a foreclosure, even if taking that risk brings the chance to start a successful small business. ${ }^{169}$ Because around half of start-up businesses fail, ${ }^{170}$ the risk is significant.

This Article does not purport to reliably predict how many economically disadvantaged persons would be willing to turn their de facto rights into collateralized credit. ${ }^{171}$ It merely observes that people invest their lifesavings into small businesses all the time, ${ }^{172}$ and that the ability to use other people's (i.e., the de jure rights holders) property rights as collateral might even cre-

167 See supra note 165 and accompanying text. Another possible reason explaining the limit might be uncertainty about the practical enforceability of the lenders' security interests. See SANJAK, supra note 155, at 5 (“[S] ocial issues [may] limit pledging or enforcement of pledges upon default.”). Any such uncertainty would likely be confronted and addressed by a jurisdiction in its process of enacting the Model Law.

168 See, e.g., Ruixun Zhang et al., The Origin of Risk Aversion, 111 Proc. Nat'L Acad. ScI. U.S. 17777, 17777 (2014) ("Risk aversion is one of the most fundamental properties of human behavior.").

169 See Dean Karlan et al., Fin. Access Initiative, Take-up: Why Microfinance Takeup Rates Are Low \& Why It Matters 10 tbl.3 (2010) (noting that the low microloan takeup rate can be partially attributed to half of eligible borrowers not wanting to go into debt); Trebilcock \& Veel, supra note 19, at 407 (observing that even with the ability to collateralize loans, economically disadvantaged parties who are "risk-averse and perceive a risk of losing their land if it is mortgaged" might not borrow). Risk aversion would likely be even greater for loans that have recourse to the borrower if the collateral is insufficient. Cf. Gregers Nytoft Rasmussen, Patience, Risk Aversion, and Economic Behavior 15 (2018), https://static-curis.ku.dk/portal/files/192466266/Ph.D.190.pdf (finding that borrower risk aversion is high in Denmark because "all mortgage loans are recourse, which implies that it is not possible to strategically default on a mortgage by walking away from the property," so "[t]he debt follows the borrower, and he remains liable to repay the potential deficiency after a foreclosure auction").

170 See infra note 183 and accompanying text.

171 Any such prediction would almost certainly require field research in the communities of holders of de facto rights. Even then, there are differences in what people say they will do and what they actually do in untested scenarios. See, e.g., Ana Villar, Response Bias, in Encyclopedia of Survey Research Methods 751, 751-52 (Paul J. Lavrakas ed., 2008) (observing that response bias can lead to flawed survey results).

172 Cf. Asheesh Advani, Tapping Your Personal Savings to Fund Your Startup, EnTrepreNEUR (June 5, 2006), https://www.entrepreneur.com/article/159522 ("[T]he most popular source of startup financing is the personal savings of the business's founder."); Martin Zwilling, Top 10 Sources of Funding for Start-ups, Forbes (Feb. 12, 2010), https:// www.forbes.com/2010/02/12/funding-for-startups-entrepreneurs-finance-zwilling.html \#577f89ae160f (discussing personal savings as the number one preferred source of funding start-up companies). 
ate an overincentive to borrow. ${ }^{173}$ Moreover, if necessary to motivate the economically disadvantaged to borrow, governments could consider subsidizing the resulting businesses or providing back-up housing as a safety net for borrowers whose businesses fail. ${ }^{174}$

\section{Explaining Why Overriding Property Law to Empower the Poor Would Be Economically Efficient}

This Article has explained from a legal standpoint how and why commercial law should override property law to enable the economically disadvantaged to use their homes and other commonly held assets as collateral. Such a legal change, however, would have broad policy ramifications. When considering a change in law that has significant policy consequences, the norm is to examine whether the benefits would justify the costs of the change. ${ }^{175}$ Although referred to in a regulatory context as a cost-benefit analysis, this is effectively a Kaldor-Hicks economic efficiency analysis. ${ }^{176}$

A project is Kaldor-Hicks efficient if its overall benefits exceed its overall costs, regardless of who bears the costs and who gets the benefits. ${ }^{177}$ Section III.A next estimates the anticipated benefits, and Section III.B then estimates the anticipated costs of overriding property law to enable the economically disadvantaged to use their homes and other commonly held assets as collateral to obtain credit. Section III.C thereafter balances those benefits and costs.

\section{A. Estimating Anticipated Benefits}

The anticipated benefits of enabling the economically disadvantaged to obtain credit are incalculably high. Assuming the disadvantaged use it to

173 I later examine this over-incentive as a possible cost. See infra notes 186-91 and accompanying text.

174 For example, the U.S. Small Business Administration (SBA) offers loan guarantees, a form of subsidy, of up to eighty-five percent for small business loans. See, e.g., Office of the Comptroller of Currency, What Is the SBA 7 (a) Loan Guaranty Program? 1 (2015). Governments worldwide likewise provide credit guarantees to stimulate small business lending. See, e.g., Sean Creehan, Fed. Reserve Bank of S.F., How Digital Innovation Can Increase Small Business Access to Finance in Asia 4 (2018). Governments could also offer housing allowances to help the disadvantaged obtain back-up housing if a loan default results in seizure of their land. Cf. E. Jay Howenstine, Foreign Housing Voucher Systems: Evolution and Strategies, 109 Monthly Lab. Rev., May 1986, at 21, 27 ("In foreign experience, the housing allowance has proved to be a highly flexible and versatile tool of national policy. Not only has it been an effective means for directly reducing excessive rent burdens on low-income families . . . but it has also provided powerful support in implementing other important national social and economic objectives.”).

175 See, e.g., Robin Paul Malloy, Law in a Market Context 190 (2004).

176 See id.; see also Steven L. Schwarcz, Changing Law to Address Changing Markets: A Consequence-Based Inquiry, 80 Law \& Contemp. Probs. 163, 167-68 (2017). Kaldor-Hicks efficiency is the practical standard used by economists to assess the economic desirability of a project.

177 MaLloY, supra note 175 , at 190. 
start small businesses, credit not only can greatly help to alleviate poverty but also can foster economic development-thereby helping to strengthen both social and financial stability. ${ }^{178}$ Economic development also has the secondary benefit of creating additional jobs. In the United States, for example, the Small Business Administration (SBA) reported that its fiscal year 2016 loans to small businesses "supported more than 587,000 jobs." 179 The World Bank similarly regards small businesses as important "drivers of local growth and job creation" in low-income countries and also lists "support for small and medium enterprises" as a "top priority in the global agenda." 180 That priority includes improving access to credit, to reduce the estimated $\$ 5.2$ trillion financing gap that is frequently identified as a barrier to those enterprises' growth. ${ }^{181}$

\section{B. Estimating Anticipated Costs}

The principal costs of overriding property law to enable the economically disadvantaged to obtain credit are threefold: direct harm to owners of the underlying de jure rights, potential subversion of the rule of law, and the loss of property by economically disadvantaged borrowers whose ventures fail. Additionally, there are transaction costs. Consider each in turn.

Owners of the underlying de jure rights would be harmed if a lender forecloses on, and thus obtains ownership of, their rights. ${ }^{182}$ Foreclosure would occur only if the borrower defaults. Ideally, borrowers who successfully invest the loan proceeds in small businesses should realize profits that enable them to repay the loans, avoiding foreclosure. Statistically, however,

178 Improved access to formal credit may also result in a lower reliance on informal sources of credit for small- and medium-sized enterprises (SMEs). The World Bank has recognized that financial inclusion and formalization of SMEs has the ancillary benefits of higher tax revenues and better regulation. See Small and Medium Enterprises (SMES) Finance, WORLD BANK, https://www.worldbank.org/en/topic/smefinance (last visited Aug. 19, 2018).

179 U.S. Small Bus. Admin., FY 2018 Congressional Budget Justification and FY 2016 Annual Performance Report 28.

180 Entrepreneurs and Small Businesses Spur Economic Growth and Create Jobs, WoRLD BANK (June 20, 2016), http://www.worldbank.org/en/news/feature/2016/06/20/entrepreneurs-and-small-businesses-spur-economic-growth-and-create-jobs. Small businesses contribute to the global economy in myriad ways, including by injecting "competition into previously stale areas," "hiring local people," and increasing business diversity "in form, function, culture, and potential," thereby making it "easier . . . for the economy to withstand tough conditions." Jose Vasquez, Why Are Small Businesses So Important for the Economy?, HuffPost (Apr. 18, 2017), https://www.huffpost.com/entry/why-are-smallbusinesses-so-important-for-the-economy_b_58f61f9ae4b048372700db75.

181 Philippe Le Houérou, Foreword to Miriam Bruhn et al., Int'l Fin. Corp., MSME Finance Gap: Assessment of the Shortfalls and Opportunities in Financing Micro, Small, and Medium Enterprises in Emerging Markets, at vii (2017), https:// www.smefinanceforum.org/sites/default/files/Data\%20Sites\%20downloads/MSME\% 20 Report.pdf; BRUHN ET AL., supra, at ix.

182 Cf. infra Annex, Model Law arts. 4(2), 8(2) (giving foreclosing lenders the ability to obtain full rights in the property pledged as collateral). 
around half of all small business start-ups fail. ${ }^{183}$ When a failure occurs, foreclosure would harm the owner of the underlying de jure rights. Although it is hard to try to quantify this harm, ${ }^{184}$ it might reach hundreds of millions of dollars or more. ${ }^{185}$ This harm might even be worse because the ability of the economically disadvantaged to use de jure property rights as collateral theoretically creates an overincentive to borrow. ${ }^{186}$

Several factors, however, should mitigate these harms to owners of the underlying de jure rights. This Article proposes to enable such owners to provide clear notice of their rights, thereby protecting those rights. ${ }^{187}$ Risk aversion, including the fact that the economically disadvantaged would lose their de facto interests in a foreclosure and thus have "skin in the game,"188 should mitigate the theoretical overincentive to borrow by aligning the

183 Matt Mansfield, Startup Statistics - The Numbers You Need to Know, Small Bus. Trends (Mar. 28, 2019), https://smallbiztrends.com/2016/11/startup-statistics-small-business.html; cf. Patricia Nilsson, London Start-ups are Most Likely to Fail, Fin. Times (Oct. 12, 2017), https://www.ft.com/content/e3c745c4-88d8-11e7-afd2-74b8ecd34d3b ("London has the lowest rate of start-up survival in the UK: only 50.1 per cent of companies formed in 2013 endured for three years, 3.6 percentage points below the national average.”). But see David Waring, Small Business Failure Rates: Why All the Stats Have It Wrong, FitSmallBusiNESS (July 26, 2017), https:/ fitsmallbusiness.com/small-business-failure-rates/ (criticizing small business failure rates as inaccurately calculated).

184 Owners of the underlying de jure rights might also be harmed if their rights are merely encumbered by a lender's security interest, which would limit their practical ability to transfer their rights or to use those rights as collateral to raise funding. Although it is even harder to try to quantify this harm, the fact that such owners tolerate or are unaware of the economically disadvantaged using their property indicates that they have little (at least current) interest in transferring their rights or using those rights as collateral to raise funding. See supra note 96 and accompanying text (observing that relatively few de jure rights holders likely know of their rights).

185 In contrast to the average microloan, which is between $\$ 100$ and $\$ 1500$, see, e.g., Matthew Swibel, Microfinance Fever, Forbes (Dec. 21, 2007), https://www.forbes.com/ forbes $/ 2008 / 0107 / 050 . h t m l \# 1 a 26 c e 06 b d 145$, the typical loan size under this Article's proposal is likely to be in the tens of thousands of dollars because de facto owners will be able to pledge their land as collateral. Even assuming a low lending rate due to risk aversion, see supra notes 168-71 and accompanying text, a start-up failure rate of fifty percent, see supra note 183 and accompanying text, suggests that de jure owners might lose property worth hundreds of millions of dollars or more in the aggregate.

186 See supra note 173 and accompanying text. To illustrate this overincentive, say that the value of full ownership_de facto and de jure-of a given property is $\$ 100,000$, and that Ignacio's de facto ownership in that property can be valued at $\$ 50,000$. Assume Ignacio borrows $\$ 80,000$, which he invests in a start-up business that is $50 \%$ likely to succeed, resulting in a total value of $\$ 140,000$, and $50 \%$ likely to fail, resulting in a total loss. The expected value of this project could be calculated as follows: $\mathrm{EV}=[50 \%$ chance of project succeeding x $\$ 140,000$ total value from that success $]+[50 \%$ chance of project failing $\mathrm{x} \$ 0$ value from that failure $]=\$ 70,000$. That represents a loss compared to the $\$ 100,000$ full ownership value of the property but a gain compared to the $\$ 50,000$ de facto ownership value of the property.

187 See supra text accompanying notes 89-93. See generally infra Section II.B (examining how recognizing de facto rights could be made fair to holders of de jure rights).

188 See supra notes 168-70 and accompanying text. 
incentives of the de jure rights holders and the disadvantaged. ${ }^{189}$ To help ensure that this alignment of incentives is meaningful, the right to include underlying de jure rights as collateral should exclude cases where the value of the de facto rights is relatively insignificant. ${ }^{190}$ This Article's suggestion to give de jure rights holders a profit-sharing upside in the start-up businesses would also help to align those incentives. ${ }^{191}$

The potential subversion of the rule of law represents a second principal cost. This cost, however, should be relatively modest. As this Article discusses, commercial law already has set strong precedents for overriding property law to achieve important policy goals and commercial realities. ${ }^{192}$ Furthermore, the law of adverse possession provides additional precedent for favoring de facto rights over de jure rights in circumstances similar to those discussed. ${ }^{193}$ Conceptually, overriding property law to enable the economically disadvantaged to obtain credit would follow these precedents.

A third principal cost is the loss of property by economically disadvantaged borrowers whose ventures fail. As discussed, around half of start-up small businesses fail. ${ }^{194}$ A borrower who loses her property in a foreclosure may become homeless. Even if the government provides a safety net, ${ }^{195}$ the costs involved might run hundreds of millions of dollars more.

Overriding property law to enable the economically disadvantaged to obtain credit also entails transaction costs. These include the costs associated with using satellite, drone, or other overhead imagery to document de facto rights and costs associated with translating that into descriptions of allocated boundaries. ${ }^{196}$ Even if these costs add up to tens of millions of dollars, they would be relatively small compared to the two hundreds-of-million-dollars cost estimates above. ${ }^{197}$

189 The law often regards partially aligned incentives as sufficient to mitigate moral hazard concerns. See, e.g., Dodd-Frank Wall Street Reform and Consumer Protection Act, Pub. L. No. 111-203, § 941, 124 Stat. 1376, 1891-92 (2010) (codified at 15 U.S.C. § 78o-11 (2012)) (requiring sponsors of securitization transactions to retain not less than five percent of the credit risk on their transactions to help align incentives and reduce moral hazard).

190 Article 4(3) of the Model Law thus provides that the "grant of a security interest in de facto rights under this Law shall not include a security interest in the underlying de jure rights if . . (b) the value of such de facto rights is insignificant compared to the value of such de jure rights." Infra Annex, Model Law art. 4(3) (b).

191 See supra note 91.

192 See supra Part I.

193 See supra notes 82-91 and accompanying text.

194 See supra note 183 and accompanying text.

195 See supra note 174 and accompanying text (discussing the possibility of housing allowances to help the disadvantaged obtain back-up housing if a loan default results in seizure of their land).

196 See supra note 115 and accompanying text.

197 See supra text accompanying notes 184-86, 194-95. If a government provides loan guarantees, see supra notes 153-54 and accompanying text, there may be additional costs which could vary depending on the loan sizes offered, the level of guarantee (e.g., fifty percent or ninety percent), and the term of the loans. See, e.g., Allan L. Riding \& George 


\section{Balancing Costs and Benefits}

The anticipated benefits of enabling the economically disadvantaged to obtain credit are incalculably high, greatly helping to alleviate poverty (thereby strengthening social stability) and also helping to foster economic development (thereby strengthening financial stability). Although the costs might be many hundreds of millions of dollars, if not more, the benefits may well exceed those costs. In that case, this Article's proposal-to enable the economically disadvantaged to obtain credit by using their de facto rights as collateral-would be economically efficient. The fact that the benefits and costs accrue to different parties-the benefits to the economically disadvantaged who hold de facto rights, the costs to the owners of the underlying de jure rights-is irrelevant to this conclusion. Economic efficiency is satisfied if the overall benefits exceed the overall costs, regardless of who benefits and who loses. ${ }^{198}$

Because its cost-benefit balancing is based on rough approximations, this Article cannot-and does not purport to-conclude that its proposal is in fact economically efficient. Nonetheless, this Article's approach to costbenefit balancing should provide a useful way of thinking about the economics of the proposal.

\section{IMPLEMENTATION}

The analysis provides a conceptual framework to explain why the economically disadvantaged should be able to use their de facto rights as collateral to obtain credit. It also explains how to legally design such a framework. Next consider how to implement such a framework, comparing statutory and judicial approaches.

Being primarily normative, this Article does not purport to comprehensively address implementation. Nonetheless, several observations may be made. As discussed, changing the law to enable the economically disadvantaged to use their homes and other commonly held assets as collateral would have broad policy ramifications. ${ }^{199}$ Legislatures, which have the capacity to hear multiple competing constituencies and to fully debate competing ideas, should consider such fundamental changes. ${ }^{200}$

Legislatures are additionally well positioned to implement this Article's framework because it is technical and deals with a somewhat specialized area of law-secured transactions. Most ordinary judges are unlikely to have sufficient commercial-law background to attempt to implement the framework.

Haines Jr., Loan Guarantees: Costs of Default and Benefits to Small Firms, 16 J. Bus. Venturing 595, 602-06 (2001) (summarizing the default rates and costs of Canada's small-business loan program).

198 See supra note 177 and accompanying text.

199 See supra note 175 and accompanying text.

200 Steven L. Schwarcz, Misalignment: Corporate Risk-Taking and Public Duty, 92 Notre Dame L. Rev. 1, 29 (2016) (citing Robert Yalden, Canadian Mergers and Acquisitions at the Crossroads: The Regulation of Defence Strategies After BCE, 55 Can. Bus. L.J. 389, 410 (2014)). 
Moreover, judges that address fact-specific cases and controversies are highly unlikely to have a sufficient mandate in any given case to implement the entire framework.

These limited observations clearly favor a statutory approach. To facilitate that approach, this Article, in the Annex, proposes a Model Law that could be considered as a basis for legislative enactment. ${ }^{201}$

This Article does not, however, necessarily exclude the option of judicial implementation. The law of adverse possession, for example, arose from judicial precedents. ${ }^{202}$ If legislatures are not prepared to help the economically disadvantaged to use their property as collateral to obtain credit, judges may wish to contemplate such law reform in appropriate cases.

\section{Conclusion}

Wealth inequality threatens social and financial stability. Enabling the poor to use their homes as collateral to obtain credit and start small businesses could greatly reduce that inequality. However, the poor cannot use their homes as collateral because they have de facto rights but lack recorded title. This is a global problem: seventy percent of the world's population lacks registered title to their homes. ${ }^{203}$ It is also a national problem, especially for members of rural African American communities.

The efforts to solve this problem have failed because, among other reasons, they focus on trying to transform property law, which is tightly bound to tradition and protecting vested ownership. This Article proposes an innovative solution: using commercial law, instead of property law, to recognize those de facto rights as collateral. This follows modern commercial law's increasing recognition of important policy goals and commercial realities as a basis to override outmoded property-law limitations.

Using commercial law to recognize those de facto rights as collateral would help to empower the poor with credit, reducing the wealth gap. It also would create incentives for the private sector to finance sustainable growth, advancing a major policy goal because the investment challenge of sustainable growth is beyond the capacity of the public sector alone.

201 In the United States, the American Law Institute and the Uniform Law Commission, which promulgate model commercial law for consideration and enactment by individual state legislatures, see supra notes 34-39 and accompanying text, should also consider the Model Law.

202 See supra notes 82-84 (observing that the roots of adverse possession come from the English common-law rule of disseisin). For an analysis showing that extending adverse possession law more widely would be a poor alternative to this Article's proposal, see supra notes 101-05 and accompanying text.

203 Why Secure Land Rights Matter, supra note 13. 
Annex: Model Law to Recognize De Facto Property Rights

\section{Preamble}

The shrinking middle class and the widening gap between the wealthy and the economically disadvantaged create threats to social and financial stability. The lack of credit significantly increases that wealth gap.

Although credit is essential to economic growth and upward mobility, many economically disadvantaged people cannot obtain credit. Because they live in homes built on land that is not legally recorded as their property or they otherwise hold property in which they have de facto but not de jure rights, they cannot use that land or other property as collateral.

This Law facilitates the ability of the economically disadvantaged to use certain de facto rights as collateral, in order to obtain credit. It also thereby creates incentives for the private sector to help finance sustainable growth.

\section{Chapter I: Scope, Interpretation, and Use of Terms}

\section{Article 1: Scope}

(1) This Law applies to security interests in both personal property and real property (real estate).

\section{Article 2: Interpretation}

(1) This law shall be liberally construed to reflect commercial realities.

(2) Nothing in this Law shall be interpreted to restrict the protections otherwise available to borrowers under consumer lending or similar law.

\section{Article 3: Use of Terms}

For purposes of this Law, the following terms shall have the following meanings:

(1) "borrower" means an economically disadvantaged person who borrows money or otherwise obtains credit under this Law;

(2) "clear notice" means notice that is physically obvious and manifestly clear, including without limitation posting no-trespassing signs, locking doors, and/or blocking entry or access to property;

(3) "collateral" means property that is subject to a security interest;

(4) "de facto rights" means rights-including those recognized or respected in practice-associated with using property or excluding the use of property by others, to the extent such rights are not formally recognized or respected under official law;

(5) "economically disadvantaged" means lacking sufficient money or other resources to live at a standard considered comfortable or normal in a society;

(6) "security agreement" means a contract granting a security interest under this Law. 
(7) "security interest" means a charge against or an interest in property to secure payment of a debt or performance of an obligation;

(8) "underlying de jure rights" means rights that are formally recognized or respected under official law, to property in which a third party has de facto rights.

\section{Chapter II: Creation of Security Interest}

\section{Article 4: Creating the Security Interest}

(1) Economically disadvantaged persons shall have the right to grant a security interest in their de facto rights as collateral, in order to obtain credit. Such right ordinarily shall be evidenced by a security agreement.

(2) Except as provided in subpart (3) below, the grant of such a security interest shall be deemed also to include a security interest in the underlying de jure rights.

(3) The grant of a security interest in de facto rights under this Law shall not include a security interest in the underlying de jure rights if (a) at any time within the 90-day period prior to the grant of a security interest in such de facto rights, there exists clear notice of the intent of the owner (provided such owner is not a governmental entity) of the underlying de jure rights to preserve such de jure rights, or (b) the value of such de facto rights is insignificant compared to the value of such de jure rights.

(4) Except as otherwise specifically permitted in Article 4(3), notice thereunder shall not impair the de facto rights of any economically disadvantaged person.

(5) Any reasonable determination made by a lender in good faith and contemporaneous with the grant of a security interest that the borrower is economically disadvantaged shall be conclusive evidence thereof.

(6) As appropriate to obtain credit, or to obtain credit on better terms and conditions, borrowers under this Law shall have the right to borrow on a joint and several basis. ${ }^{204}$ References to a borrower shall then mean such borrowers collectively, being jointly and severally liable for repayment; and references to collateral shall then mean all such borrowers' collateral collectively securing the credit.

\section{Article 5: Describing the Collateral}

(1) The collateral shall be described in the security agreement.

(2) Such description of collateral shall allocate the relevant de facto rights within the underlying de jure rights using any reasonable method.

(3) The following shall be deemed to constitute a reasonable method of allocation. Either the government, a nongovernmental organization, or a local neighborhood association organizes persons residing on the underlying

204 [This enables borrowers to manage transaction costs and could be especially useful for multiple borrowers who collectively start a business. See supra notes 161-63 and accompanying text.] 
de jure rights to allocate their de facto property rights by setting flags or other visible markers at the boundaries, which satellite or other overhead imagery would then document for translation into a description of those allocated boundaries.

(4) The allocation shall be transcribed to a searchable government record, located at [name of governmental record office].

(5) Lenders may conclusively rely on the validity and enforceability of collateral descriptions that comply with this Article 5.

\section{Chapter III: Perfection of Security Interest}

\section{Article 6: Creating Perfection}

(1) A description of collateral filed with [name of governmental mortgage-recording office] shall constitute perfection of the security interest created under this Law.

\section{Article 7: Describing the Collateral}

(1) Such description shall be deemed to be sufficient if it provides notice that the collateral may be subject to a security interest under this Law.

(2) A standard description of the underlying de jure rights in which the security interest is allocated shall be deemed to constitute a sufficient description. This description could copy the existing recorded description of the underlying de jure rights; it need not describe the allocated rights per se.

\section{Chapter IV: Foreclosure on Security Interest}

\section{Article 8: Foreclosure}

(1) Upon default by the borrower under a security agreement, the lender shall have the right to exercise remedies against the collateral to the extent provided after default under otherwise applicable secured transactions law.

(2) To the extent the grant of a security interest is deemed, under Article 4 of this Law, also to include a security interest in the underlying de jure rights, the lender's remedies under Article 8(1) shall extend to those underlying de jure rights. ${ }^{205}$

\section{Chapter V: Government Assistance ${ }^{206}$}

Article 9: Government Guarantees

(1) At its option, [name of government agency] may guarantee repayment of all or a portion of any loans made under this Law.

205 [The Model Law could also give holders of the underlying de jure rights a profitsharing upside potential in the business started by the borrower, to help to balance the risk that holders could lose their rights in a foreclosure. See supra note 91].

206 [Chapter $\mathrm{V}$ is an optional part of the Law.] 
(2) Such a guarantee may be made on whatever terms and conditions [name of government agency] deems appropriate from time to time. ${ }^{207}$

\section{Article 10: Government Loans}

(1) At its option, [name of government agency] may make direct loans under this Law.

(2) Such a loan may be made on whatever terms and conditions [name of government agency] deems appropriate from time to time. ${ }^{208}$ 